\title{
A synoptic decomposition of rainfall over the Cape south coast of South Africa
}

\author{
Christien J. Engelbrecht, Willem A. Landman, Francois A. Engelbrecht, Johan Malherbe
}

\begin{abstract}
A synoptic climatology is derived for the Cape south coast region of South Africa by application of the self-organizing map (SOM) technique. The SOM is applied to average daily low-level circulation fields, as represented by sea-level pressure anomalies for the period 1979-2011. This coastal region receives rainfall all-year round with slight peaks during March-April and with more pronounced peaks during August and October-November. The synoptic forcing responsible for this annual multimodal rainfall distribution is identified, and the relative contribution of different synoptic types to the annual rainfall is quantified. Ridging high pressure systems contribute to $46 \%$ of the annual rainfall, while tropical-temperate troughs contribute $28 \%$. Cut-off lows (COLs) co-occurring with ridging highs and tropical-temperate troughs are associated with $16 \%$ of the annual rainfall total. The contribution of ridging high pressure systems decreases from south to north, whilst the opposite is true for tropical-temperate troughs. COLs, ridging high pressure systems and tropicaltemperate troughs are associated with the March-April rainfall peak, while COLs are largely associated with the
\end{abstract}

C. J. Engelbrecht $(\bowtie) \cdot J$. Malherbe

Institute for Soil, Climate and Water, Agricultural Research

Council, Pretoria, South Africa

e-mail: engelbrechtc@arc.agric.za

C. J. Engelbrecht · W. A. Landman

Department of Geography, Geoinformatics and Meteorology,

University of Pretoria, Pretoria, South Africa

W. A. Landman · F. A. Engelbrecht

Climate Studies, Modelling and Environmental Health, CSIR

Natural Resources and Environment, Pretoria, South Africa

F. A. Engelbrecht

GAES, University of the Witwatersrand, Pretoria, South Africa
August rainfall peak. Ridging high pressure systems and to a lesser extent tropical-temperate troughs, are responsible for the October peak observed along the coast, while the November peak over the adjacent interior regions is associated with COLs that occur in combination with the tropical-temperate troughs during this month.

Keywords All-year rainfall region - Cape south coast of South Africa · Synoptic types · Cut-off lows · Ridging high pressure systems

\section{Introduction}

The Cape south coast of South Africa (Fig. 1) receives rainfall all-year round, with peaks during autumn and spring (e.g. Taljaard 1996; Weldon and Reason 2014). The allyear nature of rainfall of this region is in strong contrast to the pronounced seasonality that characterizes rainfall over most of South Africa: the country is largely a summer rainfall region (e.g. Fauchereau et al. 2009), with winter rainfall occurring over the southwestern Cape area (Fig. 1) (e.g. Philippon et al. 2011). The southern areas of South Africa largely receive rainfall from organized synoptic-scale weather systems (Tennant and Hewitson 2002), whilst rainfall over the northern and eastern interior regions are mostly of a convective and sometimes tropical nature (e.g. Malherbe et al. 2012). The all-year rainfall region of the Cape south coast, which to some extent may be thought of as forming a boundary region between the winter and summer rainfall regions, is meteorologically one of the more complex regions of South Africa. Rainfall over the region results from well-defined mid-latitude systems, tropical systems and convection from the north, and complex interactions and linkages between these very different systems. 
Fig. 1 The geographic location of the study region within South Africa (indicated by the rectangle - solid black lines). The three sub-regions of interest, labeled as Region 1, Region 2 and Region 3, are delineated by the black dotted lines on the zoomed-in view of the study region. Numbers $1-22$ indicate the selected rainfall stations used in the analysis of rainfall attributes. The background shaded color contours of the mean annual rainfall are based on the ARC in-house developed gridded rainfall dataset

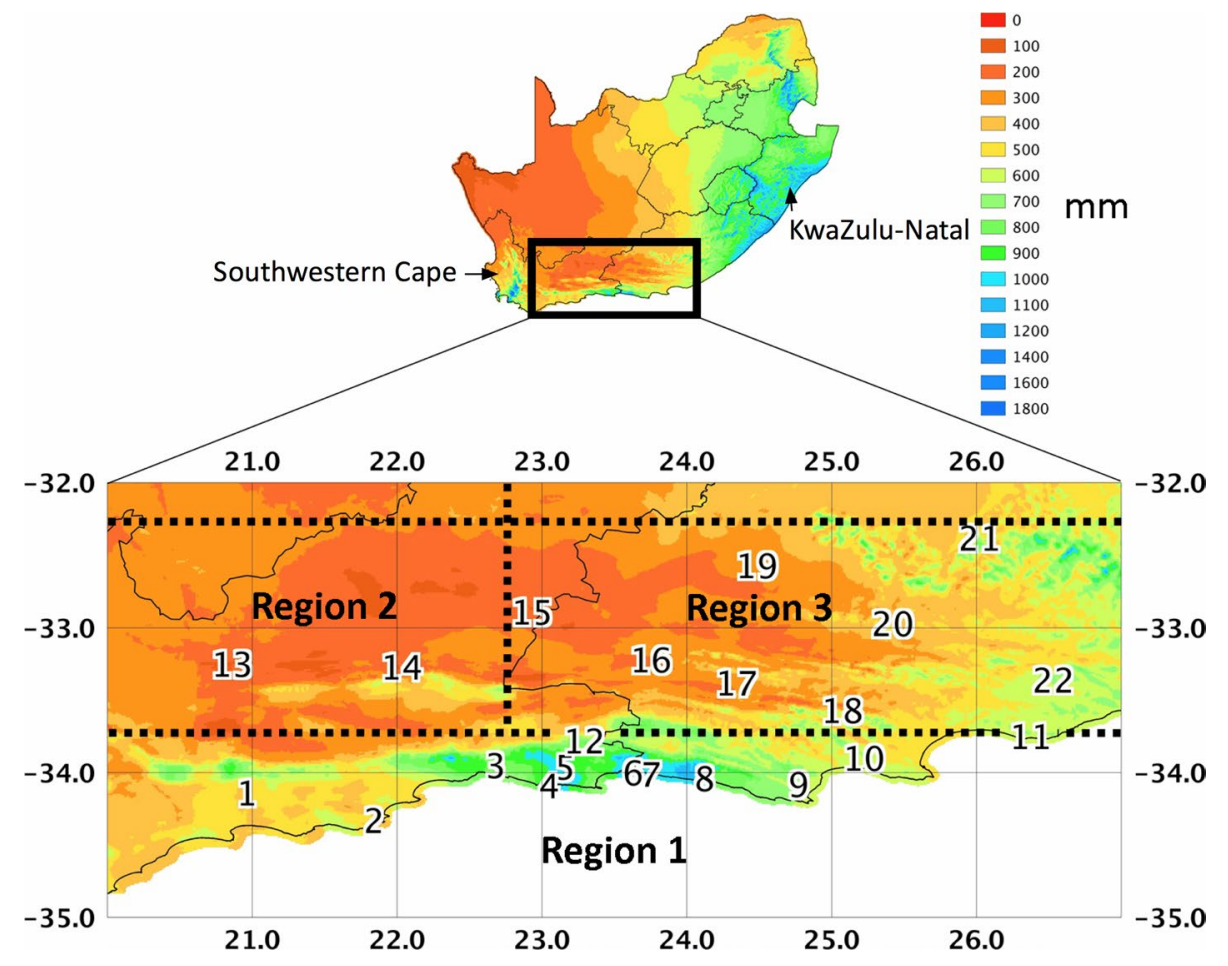

Superimposed on the synoptic circulation there are also meso-scale circulation systems, which result from interactions of the larger scale flow with mountainous topography inland of the coastal area and the moisture laden air above the Agulhas current flowing along the Cape south coast of South Africa. (e.g. Rouault et al. 2002; Singleton and Reason 2006).

Mid-latitude weather systems bringing rainfall to the Cape south coast include cold fronts, west-wind troughs, cut-off lows (COLs) and ridging high pressure systems (e.g. Taljaard 1996; Favre et al. 2013; Weldon and Reason 2014). When rainfall over the region is of a tropical nature, it is usually from tropical-temperate trough cloud bands (e.g. Taljaard 1996; Hart et al. 2013). Of the different rain bearing systems, it is mostly COLs that are associated with high-impact events over the region. In fact, across South Africa, COLs are known to on occasion produce 24-h rainfall totals exceeding the relevant climatological monthly rainfall total at particular locations (e.g. Singleton and Reason 2006, 2007a; Muller et al. 2008). These systems can be extremely hazardous, producing floods with consequent damage to infrastructure and sometimes loss of life (Weldon and Reason 2014). An important example is the Laingsburg floods of January 1981, in which 104 people drowned in a flood of the Buffels river (Roberts and Alexander 1982; Singleton and Reason 2007b). To date, the most rainfall that has been recorded from a single COL event occurred during September 1987 when the 3-day rainfall total along the KwaZulu-Natal coast exceeded
$900 \mathrm{~mm}$ (Singleton and Reason 2007b). COLs have also been associated with numerous extreme rainfall events along the Cape south coast (e.g. Hayward and van den Berg 1968, 1970; Rouault et al. 2002; Singleton and Reason 2006, 2007a), with the COL event during September 1968 causing floods in the Port Elizabeth area as $500 \mathrm{~mm}$ rain fell within 24-h. These high-impact rainfall events may have led to a perception that COLs are the main rain-producing weather systems over the region.

However, the relative contributions of different weather systems in causing rainfall over the Cape south coast have not been formally quantified. Recently, the contribution of COLs to rainfall over the southern African region has been analysed by Favre et al. (2013). COLs have been shown to explain a higher proportion (more than $20 \%$ ) of rainfall totals over the Cape south coast compared to the winter and summer rainfall regions (Favre et al. 2013). For this region, the largest contribution of COLs to rainfall is experienced during the period July to September (JAS), compared to the periods October to December (OND), April to June (AMJ) and January to March (JFM) when the lowest contribution of COLs to rainfall is experienced (Favre et al. 2013). Apart from COLs, ridging high pressure systems have also been recognised as important in contributing to rainfall over the mountainous regions bordering the Cape south coast (e.g. Weldon and Reason 2014). In fact, it has been suggested that COLs are responsible for the autumn rainfall peak, with ridging high pressure systems driving the spring rainfall peak over the all-year rainfall region (Jury 
and Levey 1993). However, the contribution of ridging high pressure systems to rainfall over the Cape south coast has not been quantified to date. The weather system responsible for the bulk of summer rainfall over the southern African region is the tropical-temperate trough, characterized by a north-west to south-east aligned cloud band that develops as a result of the interaction between a tropical low and a temperate westerly wave by means of a subtropical trough (Washington and Todd 1999). Tropical-temperate troughs cause on the average about $39 \%$ of rainfall over the summer rainfall region (Crimp et al. 1997). The maximum frequency of occurrence of tropical-temperate troughs is during November (Hart et al. 2013), when they are also responsible for $30-60 \%$ of rainfall occurring along the Cape south coast (Hart et al. 2013). Their relative contribution for December remains high (30-50 \%) (Hart et al. 2013).

The main aims of this paper are to objectively determine the relative importance of different synoptic types in causing rainfall over the Cape south coast, and to gain more insight into the synoptic climatology that results in the region's all-year rainfall uniqueness. Of particular interest is the relative importance of ridging highs in causing rainfall over the Cape south coast (i.e. compared to COLs). Interactions between ridging highs and COLs, and tropical-temperate troughs and COLs in causing rainfall over the region are also considered.

\section{Data and methodology}

\subsection{Weather station data}

Rainfall station data for the Cape south coast and adjacent interior extending to the southern escarpment were selected based on completeness (more than $66 \%$ of the days in a particular month need to be present and pass data quality tests) of daily rainfall records for the period 1979-2011. Twenty-two weather stations from the South African Weather Service (SAWS) complied with the desired criteria (see Fig. 1 for the locations of the selected stations). The selected station data were subjected to extreme and missing value tests to ascertain data quality. Entries failing these tests were replaced by estimated values derived from neighbouring stations. The beginning of the study period was selected to be 1979, as reanalysis data from the National Centers for Environmental Prediction (NCEP) (Kalnay et al. 1996) prior to 1979 do not have the advantage of satellite data being incorporated into the reanalysis procedure (Tennant 2004). The station data are used in the research to quantify the contribution of different synoptic types to rainfall over the Cape south coast and adjacent interior regions.

\subsection{Gridded data}

Two independently constructed gridded rainfall datasets, the Famine Early Warning System (FEWS) and the Climatic Research Unit (CRU) version TS3.1, were utilized for the delineation of the all-year rainfall region. Gridded data were used for this purpose rather than the station data described above, due to the uneven distribution in space of stations with records of sufficient length and quality. The FEWS data are a merged satellite-gauge gridded daily rainfall dataset with a resolution of $0.1^{\circ}$ longitude by $0.1^{\circ}$ latitude, with records commencing in January 1983 (Sylla et al. 2013). The CRU TS3.1 monthly gridded rainfall dataset has a resolution of $0.5^{\circ}$ longitude by $0.5^{\circ}$ latitude, is based solely on station data and is available for the period 1901-2009 (Harris et al. 2014). The all-year rainfall region may be defined using the following criteria as guidelines:

- The ratio of the rainfall amount for the month of minimum rainfall to rainfall of the month of maximum rainfall is relatively high compared to regions of strong seasonality.

- Each month of the year needs to be associated with at least $5 \%$ of the annual rainfall. This $5 \%$ threshold is based on graphs produced by Taljaard (1996), where the monthly contribution to the annual rainfall for various rainfall regions as identified by van Rooy (1972) is presented.

- The average monthly fluctuation of rainfall relative to the average monthly rainfall over the all-year rainfall region should be small compared to that of the winter and summer rainfall regions (see Sect. 3 for details).

It may be noted that prior to using the gridded datasets for the purpose of identifying the spatial extent of the allyear rainfall region, it was first established that these rainfall sets sufficiently describe the annual rainfall cycle over South Africa. This was achieved through a comparison of the monthly rainfall climatologies of the gridded datasets against those of the selected weather stations, as well as those of a third gridded rainfall climatology. The latter was developed at the Agricultural Research Council (ARC), using station data from both the ARC and SAWS. Despite the general underestimation of rainfall totals over Africa in FEWS data, in particular over regions of orography (Sylla et al. 2013), both datasets have been found to give representations of the area of all-year rainfall consistent with the raw weather station data and the mentioned ARC dataset. The mean annual distribution of rainfall over South Africa, as described by the ARC dataset, is shown in Fig. 1. Note that mean annual rainfall totals exceeding $1,000 \mathrm{~mm}$ occur in places along the Cape south coast. 


\subsection{Atmospheric circulation data}

Daily averaged sea-level pressure (SLP) and geopotential height data of the $850,700,500$ and $200 \mathrm{hPa}$ pressure levels from NCEP reanalysis data, NCEP 1 (Kalnay et al. 1996), for the period January 1979 to December 2011 are utilized. The NCEP data has a horizontal resolution of $2.5^{\circ}$ by $2.5^{\circ}$ and a vertical resolution of 17 pressure levels. The daily weather over the Cape south coast region is strongly dependent on the low-level circulation, and the main source of moisture is the ocean. In particular, major rainfall events over the region are associated with the low-level moisture flux originating from the Agulhas current to the southeast (e.g. Rouault et al. 2002; Singleton and Reason 2006, 2007a). Therefore, daily SLP is employed for the identification of low-level circulation patterns.

\subsection{Weather pattern identification}

Weather patterns that influence the Cape south coast region of South Africa were objectively identified by application of the self-organizing map (SOM) technique (Kohonen 2001). The technique is based on an unsupervised nonlinear clustering algorithm that organizes the input data into a user-specified number of nodes that span the continuum of types in the input data. The technique is well suited for weather pattern identification where the daily transitions between weather patterns are important (Hewitson and Crane 2002). SOMs are increasingly being employed in climate studies focusing on the southern African region (e.g. Hewitson and Crane 2002; Tennant and Hewitson 2002; Tozuka et al. 2014; Van Schalkwyk and Dyson 2013). NCEP reanalysis daily averaged SLP data for the period 1979-2011 was used to develop a SOM relevant to the Cape south coast region. Atmospheric circulation, here the SLP circulation, is driven by the SLP gradients and do not depend on the actual magnitudes of the SLP (Schuenemann et al. 2009). To obtain the required daily gradient fields, the daily domain average of SLP was subtracted from the SLP at each grid point. The SOM was constructed for the region $45^{\circ} \mathrm{S}-32.5^{\circ} \mathrm{S}$ and $10^{\circ} \mathrm{E}-40^{\circ} \mathrm{E}$. The selected region allows for capturing the progression of high pressure systems and troughs, advancing from west to east, to the south of the Cape south coast. The northern boundary of the SOM region was purposefully selected to extend to only $32.5^{\circ} \mathrm{S}$. If this boundary is chosen further to the north, to include most of the interior of South Africa, the synoptic types identified by the SOM are dominated by the prevailing wintertime high pressure systems over the interior. Furthermore, SLP is used as a variable to develop the SOM, as the circulation over the oceans bordering the subcontinent is crucial in inducing rainfall over the Cape south coast (see Sect. 2.3). It may be noted that tropical-temperate trough linkages are captured with the SOM configuration as described, even though the northern boundary of the SOM region is limited to the extreme southern parts of the interior (see Sect. 3). The typical SLP patterns associated with COLs (e.g. Taljaard 1985; Tennant and van Heerden 1994) are also captured. For the purpose of this study, it is appropriate to apply a relatively large SOM to avoid over generalizing the richness of weather patterns that occur over the region into a too small number of nodes (synoptic types). SOMs that classify daily SLP circulation into 12, 20 and 35 synoptic types, respectively, have been considered. It was found that the 12 and 20 node SOMs do not capture the various stages of sea-level anticyclones, ridges and troughs adequately. Of particular importance, is that the known variations in the position and amplitude of SLP ridges and troughs that are representative of weather patterns ranging from weak synoptic flow to tropical-temperate troughs and COLs, are well represented in the SOM. Capturing the variations in ridging anticyclones is important as the rainfall produced by these systems is influenced by the nature of the onshore flow onto the coastal mountains (e.g. Taljaard 1985; Weldon and Reason 2014). Topographically induced rainfall occurs on the seaward side of the west-east orientated Cape Folded mountain range along the Cape south coast (Philippon et al. 2011), where strong topographic gradients are found (Singleton and Reason 2006). Figure 2 shows a map of the topography as represented
Fig. 2 Topography of the Cape south coast as represented by SRTM DEM data. The Cape Folded mountain range is indicated by the black rectangle
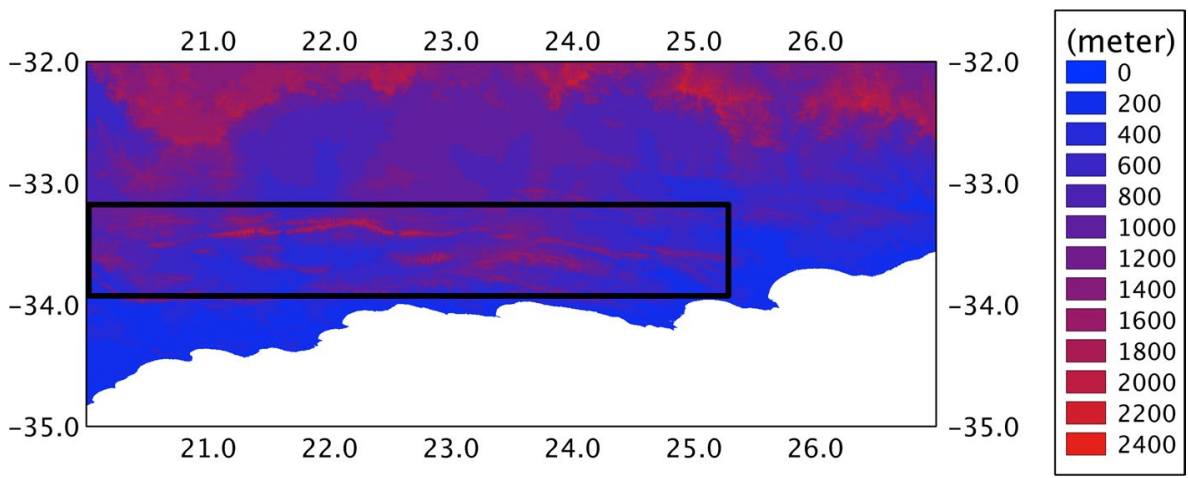
by the Shuttle Radar Topography Mission (SRTM) digital elevation model (DEM) data (Weepener et al. 2012). Some peaks of the Cape Folded mountain range are of comparable elevation to the mountains found over the interior plateau located further northwards (Fig. 2).

Following Schuenemann et al. (2009), the statistical significance of the frequency for which the daily SLP anomalies map to each node is determined by calculating a $95 \%$ confidence interval around the probability that any daily SLP anomaly would map to any node $(2.86 \%$ for the $7 \times 5$ SOM used in this study). By assuming that the process is binomial, the $95 \%$ confidence limits are calculated by

$p \pm 1.96\left[\frac{p(1-p)}{n}\right]^{1 / 2}$,

where $p$ is $2.86 \%$ (the probability that any daily SLP anomaly field would map to any node) and $n$ is 12,053 (number of daily SLP anomaly fields). The calculated confidence interval around $2.86 \%$ is $2.56-3.15 \%$. The observed frequency of a node is considered significantly different from $2.86 \%$ at the $95 \%$ confidence level if it falls outside this calculated interval.

\subsection{Identification of cut-off lows}

On the average, only about 11 COLs occur annually over the southern African region (Singleton and Reason 2007b), implying that these systems would not feature as a standalone synoptic type in the $7 \times 5$ SOM based on daily circulation fields presented in this paper. Indeed, COLs may occur in conjunction with a number of different low-level circulation patterns-most commonly in association with a strong ridge of high pressure in the low-levels polewards of the upper COL (e.g. Taljaard 1985; Tennant and van Heerden 1994; Katzfey and McInnes 1996; Favre et al. 2012), in combination with tropical-temperate troughs (Hart et al. 2013), and further, as a COL system evolves, in association with the evolving high pressure system (ridging progressively from the southwest to southeast of South Africa). The typical low-level circulation associated with tropical-temperate troughs-a meridional trough that links the Angola low and a mid-latitude wave/cyclone, is illustrated in Tennant (2003) and Hart et al. (2010, 2012). An objective tracking methodology is therefore used in order to study the effects of these important rainfall producing systems on rainfall attributes over the Cape south coast region.

NCEP reanalysis data (Kalnay et al. 1996) was utilized for the purpose of identifying and tracking COLs over the period 1979-2011. Over South Africa, COLs exhibit a typical length scale of $1,000 \mathrm{~km}$ (e.g. Singleton and Reason 2007b) and are therefore well resolved on the $2.5^{\circ}$ resolution grid of the NCEP data. In this paper, a $\mathrm{COL}$ is defined as a closed-low (a local minimum in the geopotential height at the $500 \mathrm{hPa}$ level) that possesses a cold core, following the criteria used by Favre et al. (2012). The daily-average geopotential height and temperature fields at $500 \mathrm{hPa}$ are utilized for identifying and tracking COLs. All COLs that occurred for at least 24-h within the domain bounded by $40^{\circ} \mathrm{S}-20^{\circ} \mathrm{S}$ and $10^{\circ} \mathrm{E}-40^{\circ} \mathrm{E}$ are considered in this study. The closed-lows are identified and tracked by applying an objective, automated tracking algorithm. Geopotential minima are identified by comparing the geopotential of each grid point in the domain bounded by $40^{\circ} \mathrm{S}-20^{\circ} \mathrm{S}$ and $10^{\circ} \mathrm{E}-40^{\circ} \mathrm{E}$, to the geopotential values of the square of eight surrounding grid points on the latitude longitude grid. Closed-low tracks are constructed by identifying the geopotential minima of time step $t+l$ nearest to the geopotential minima at time step $t$, provided that this distance is $<1,000 \mathrm{~km}$. This distance implies that closedlows are assumed to have a mean daily speed that do not exceed $42 \mathrm{~km} / \mathrm{h}$ (Favre et al. 2012). The tracking procedure is developed in such a manner that any geopotential minima can only be part of a single track (see Engelbrecht et al. 2013 for details). To identify the COL tracks from the database of closed-low tracks, the approach utilized by Favre et al. (2012) is applied in this study. All the closedlow tracks identified through the procedure outlined above are subsequently subjected to tests described in Favre et al. (2012) to ensure that it is of extra-tropical origin, detached from the westerlies and has a cold-core. Figures 3 and 4 show the geographical distribution (expressed as the number of COL days per grid point) and the annual cycle in the number of COLs for the domain $40^{\circ} \mathrm{S}-20^{\circ} \mathrm{S}$ and $10^{\circ} \mathrm{E}-40^{\circ} \mathrm{E}$ respectively. There are two geographical regions of preferred COL day occurrence, namely in the Mozambique Channel as well as over the Atlantic Ocean extending in

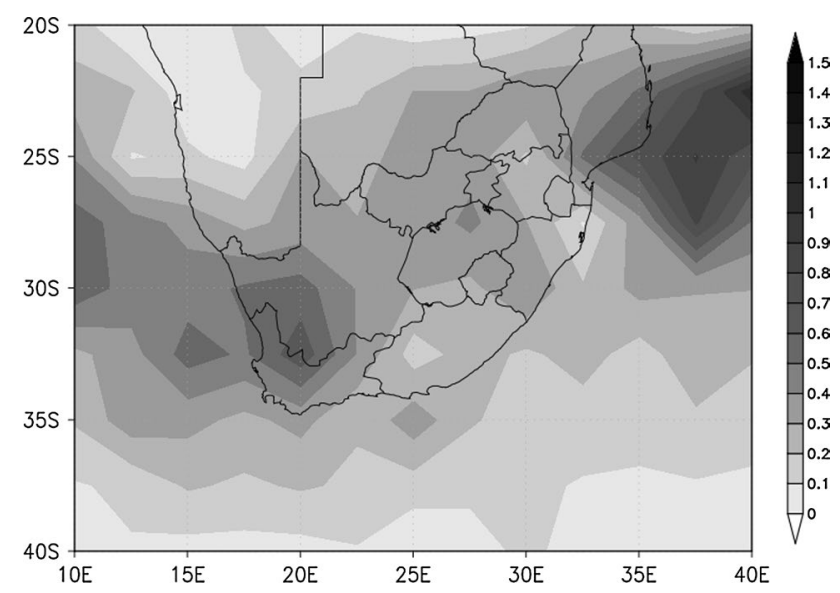

Fig. 3 Mean annual COL frequency over the domain $40^{\circ} \mathrm{S}-20^{\circ} \mathrm{S}$ and $10^{\circ} \mathrm{E}-40^{\circ} \mathrm{E}$ expressed as the number of $\mathrm{COL}$ days per grid point 
Fig. 4 Annual cycle of COLs over the domain $40^{\circ} \mathrm{S}-20^{\circ} \mathrm{S}$ and $10^{\circ} \mathrm{E}-40^{\circ} \mathrm{E}$ expressed as the monthly mean number of COL events

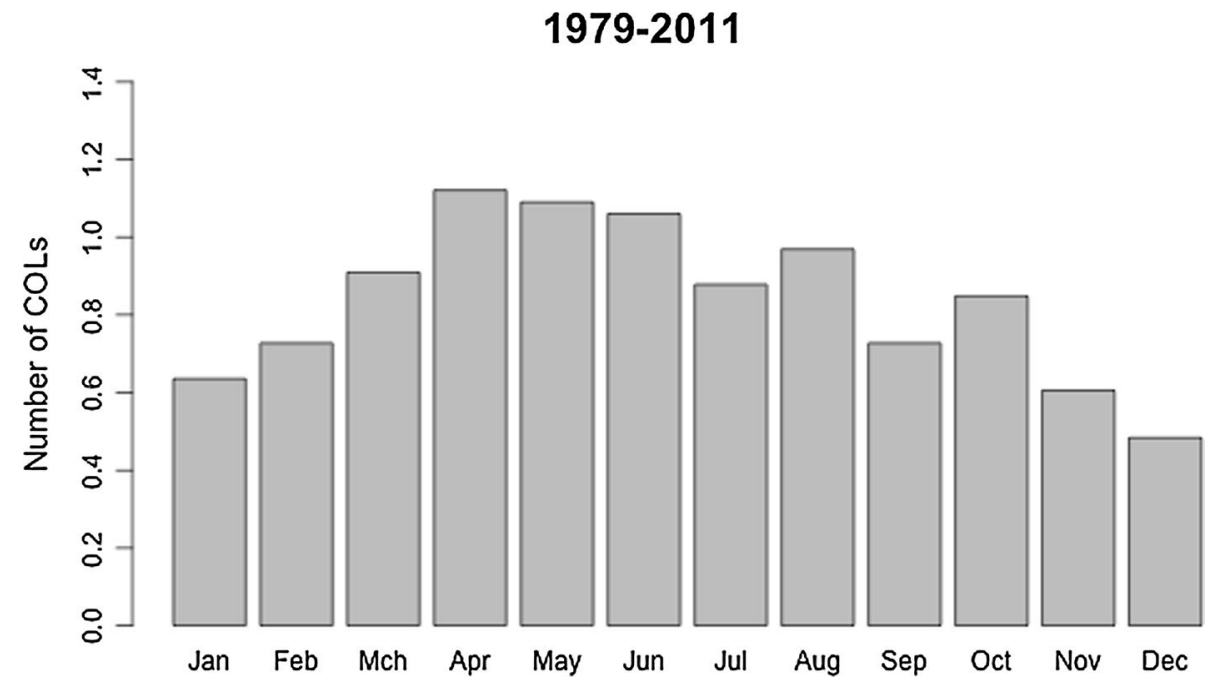

over the southwestern part of South Africa (Fig. 3). The spatial pattern of the geographical distribution of COL days identified in this study is in good agreement with that of Favre et al. (2013), while the two regions of preferred COL occurrence correspond with the two quadrants representative of the highest frequency distribution of the number of COLs as found by Singleton and Reason (2007b). COL events peak during autumn (Fig. 4, March-May) with the least occurrence in November-January (Fig. 4), consistent with the findings of Taljaard (1985), Singleton and Reason (2007b) and Favre et al. (2013).

Rainfall associated with cold-cored systems occurs mainly some hundreds of kilometers to the northeast, east and southeast of the centers of these systems (Taljaard 1995). From the constructed COL dataset for the period 1979-2011, all the COLs that occurred west of $32.5^{\circ} \mathrm{E}$ were considered to be potentially responsible for rainfall over the region (e.g. Favre et al. 2013). Such COLs associated with rainfall over the study region, at least at a single station, are defined as rainfall producing COLs. Finally, for each day that a COL was identified as a rain-producing weather system over the study area, the circulation of that day was mapped onto the synoptic types identified by the SOM. This enables the identification of the synoptic types that are most frequently associated with COLs that influence the study area.

\subsection{Relating rainfall to the identified synoptic types}

To relate rainfall to the main synoptic types identified by the SOM, daily rainfall data (1979-2011) for weather stations in the Cape south coast region and adjacent interior were mapped to the SOM. That is, for each day in the timeseries the relevant circulation pattern may be associated with one of the SOM's synoptic types (e.g. Tennant 2003). The corresponding daily rainfall totals are subsequently associated with the relevant synoptic type, on a stationby-station basis. This enables calculating the percentage of annual rainfall associated with a specific synoptic type for each station in the region. Note that the study region allows for the contributions of different synoptic types to rainfall over the all-year rainfall region to be compared to contributions to rainfall over the summer rainfall region to the north (Fig. 1). The spatial distribution of rainfall over the study region exhibits a marked north-south gradient, with annual rainfall totals exceeding $1,000 \mathrm{~mm}$ along the Cape Folded mountain range in the south whilst less than $200 \mathrm{~mm}$ of rain is observed over the Karoo just north of the Cape Folded mountain range. Further to the east, over the interior of the study region, the annual rainfall totals vary between 300 and $700 \mathrm{~mm}$. These different rainfall distributions were used to identify three separate regions for which rainfall was categorized according to the different synoptic types (see Sect. 3 for details). The percentage contribution by each node to the annual rainfall for a particular region was calculated by averaging the percentage contributions to rainfall recorded at each of the weather stations in the particular region.

\section{Results}

3.1 Attributes of rainfall over the Cape south coast and adjacent regions

\subsubsection{Spatial extent of the all-year rainfall region}

Application of the criteria describing all-year rainfall attributes (see Sect. 2.2) on CRU TS3.1 and FEWS mean monthly rainfall data, yields remarkably similar spatial patterns (Fig. 5) - across the three different metrics, and across the two data sets. Qualitatively, the metrics indicate 
(a) $\mathrm{CRU}$

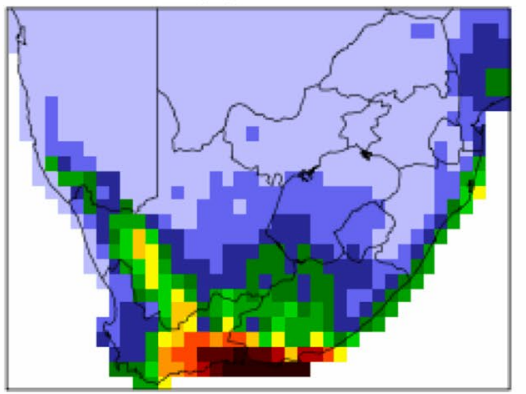

(\%)

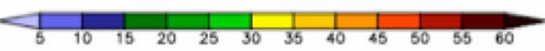

(b) FEWS

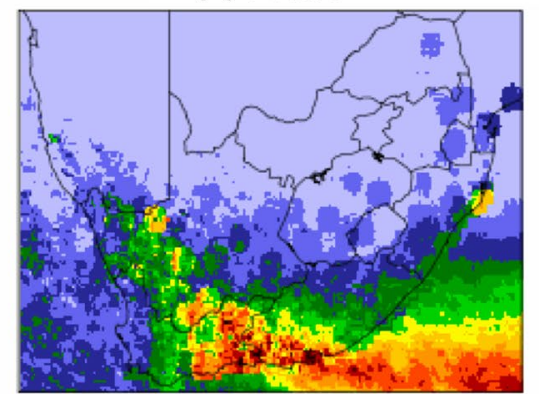

(c) $\mathrm{CRU}$

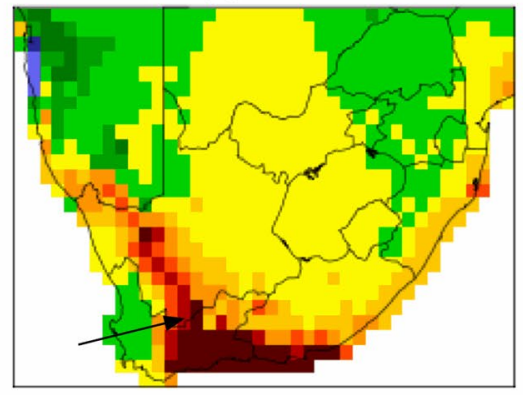

Number of months

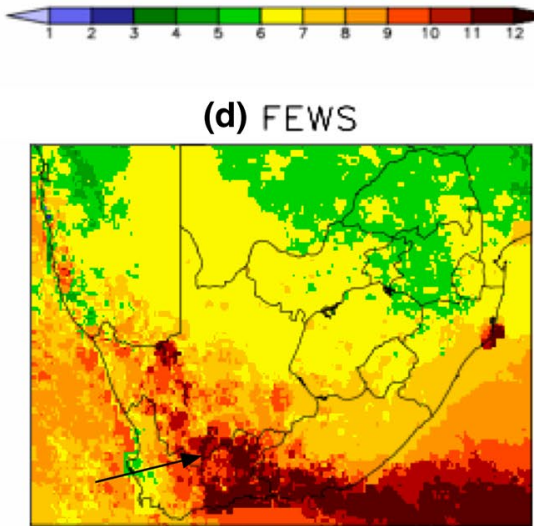

(e) CRU

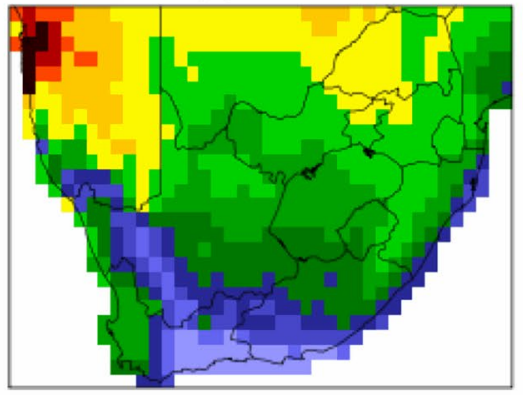

(\%)

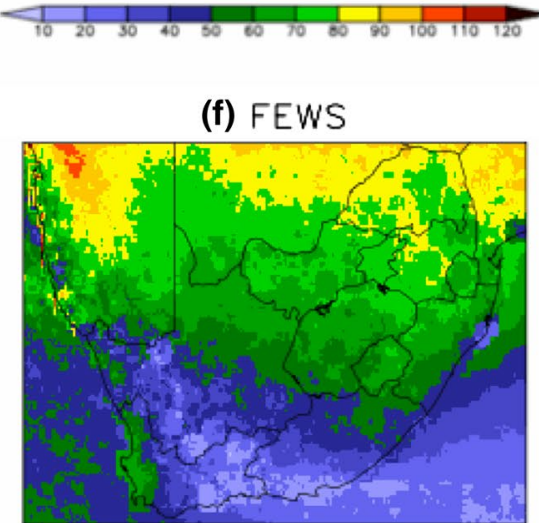

Fig. 5 Delineation of rainfall regions in South Africa according to the ratio of the month of minimum rainfall to the month of maximum rainfall $(\mathbf{a}, \mathbf{b})$, the number of months for which the mean monthly rainfall total contributes $5 \%$ or more to the mean annual rainfall total $(\mathbf{c}, \mathbf{d})$, and the average fluctuation of monthly rainfall from the monthly mean rainfall expressed as a percentage $(\mathbf{e}, \mathbf{f})$, calculated from CRU (a, c, e) and FEWS (b, d, f) data for the period 1983-2009 that the spatial extent of the area receiving rainfall all-year round along the Cape south coast is found within the collective boundaries described in other studies (e.g. Taljaard 1996; Landman et al. 2001; Rouault and Richard 2003; Weldon and Reason 2014). Along the coast, the all-year rainfall region is found approximately between $21^{\circ} \mathrm{E}$ and $27^{\circ} \mathrm{E}$, while its northern extent is mostly restricted by the Cape Folded mountain range (Fig. 2). The extent of the all-year rainfall region is well illustrated by the metric of the number of months of the year that receive $5 \%$ or more of the annual rainfall. In both CRU (Fig. 5c) and FEWS (Fig. 5d), 11-12 months of the year satisfies the criteria over the mentioned area. Weather stations number 1-12 in Fig. 1 are located in this region-and all receive $5 \%$ or more of the annual rainfall total during each month of the year. This region will be referred to as Region 1 in the study and from here onwards is regarded to define the Cape south coast (or all-year rainfall) region. The data from weather stations number 1-12 as seen on Fig. 1 are used for the analysis concerning rainfall attributes of Region 1. From the western part of the all-year rainfall region along the Cape south coast, a relatively narrow region that exhibits pseudo all-year rainfall characteristics extends northwards, to the east of the western escarpment (see the arrows in Fig. 5c, d). As the main focus of this study is on the Cape south coast, this secondary all-year rainfall region is analysed separately as Region 2. It is defined to have $32.3^{\circ} \mathrm{S}$ as northern boundary and $22.8^{\circ} \mathrm{E}$ as eastern boundary, and includes weather stations number 13 and 14 (Fig. 1). For these two stations all months, with the exception of September, receive $5 \%$ or more of the annual rainfall. Region 3 comprises of weather stations number 15-22. Region 3 exhibits summer rainfall characteristics, as seen in the ratio of the month of minimum rainfall to the month of maximum rainfall (Fig. 5a, b). For the stations located in this region, at least 3 months receive on the average monthly rainfall totals that are less than $5 \%$ of the annual rainfall. It may finally be noted that there is a small area along the north coast of KwaZulu-Natal that also exhibits all-year rainfall attributes, according to the metrics presented in Fig. 5. The circulation dynamics of this region are likely to be very different to that of the Cape south coast, and its investigation falls beyond the scope of the current paper. 


\subsubsection{Annual rainfall cycle}

The annual rainfall cycle over Region 1 (based on the monthly rainfall totals averaged over weather stations number 1-12) exhibits 3 peaks (Fig. 6). These peaks occur during March-April, August and October, with the October peak of $80 \mathrm{~mm}$ being the highest (monthly totals averaged over the period 1979-2011 are shown). A rainfall hiatus occurs in September. Region 2 has rainfall peaks during April and November (based on weather stations number 13 and 14), with April the month with the highest rainfall total. Over Region 3, a summer rainfall region, rainfall peaks over the period November to March. The November peak is slightly higher than the February-March peak.

(a) Area-averaged rainfall: Region 1

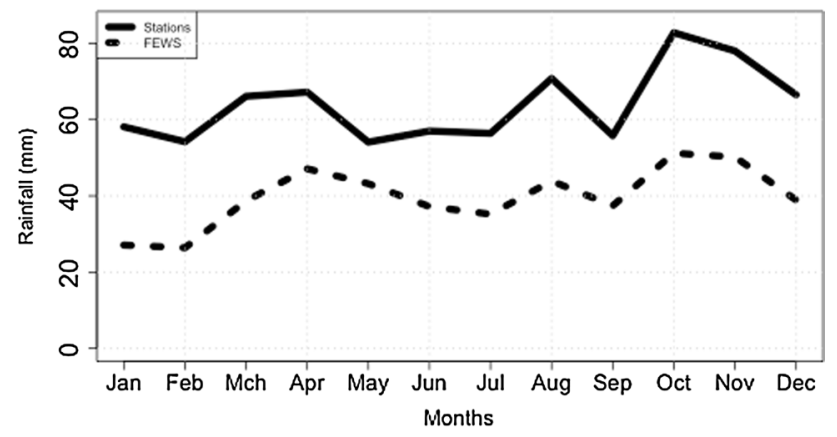

(b) Area-averaged rainfall: Region 2

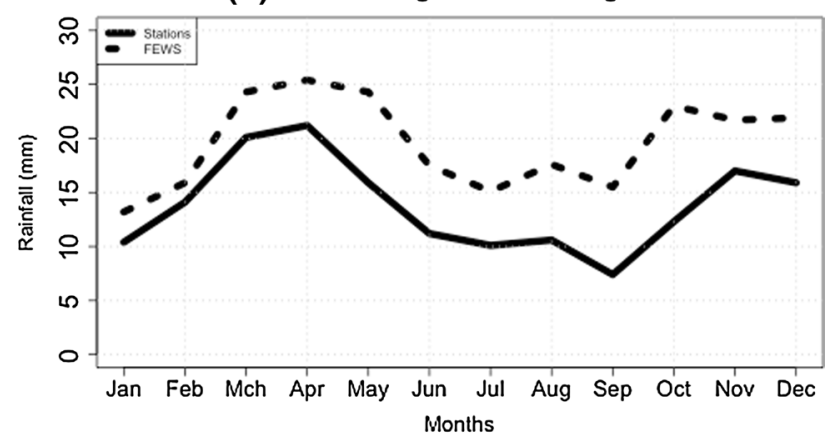

(c) Area-averaged rainfall: Region 3

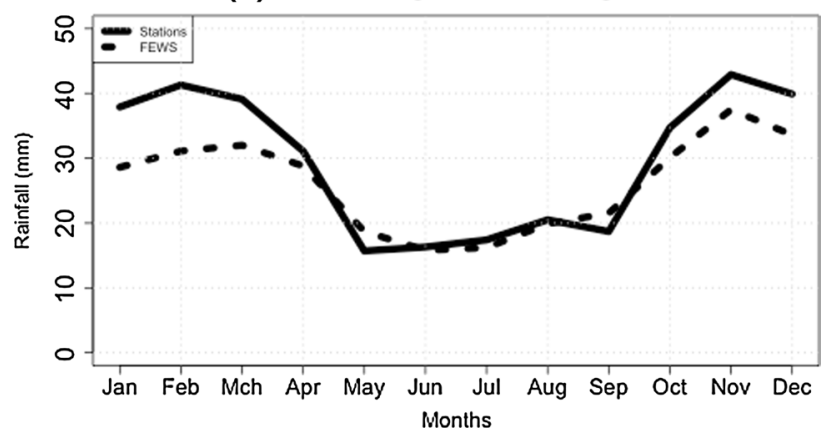

Fig. 6 Area-averaged annual rainfall cycle for the period 1979-2011 over a Region 1, b Region 2 and $\mathbf{c}$ Region 3 as described by weather station data (solid line) and FEWS rainfall (dotted line)
The September rainfall hiatus is present over Regions 2 (Fig. 6b) and 3 (Fig. 6c) as well, although less prominent in amplitude compared to the Region 1 hiatus. (Fig. 6a). A key objective of the paper is to explain the existence of the three rainfall peaks of Region 1, from a synoptic type perspective.

Regarding the delineation of the all-year rainfall region, the application of the all-year rainfall criteria on CRU and FEWS rainfall data produced in general similar results and is useful to describe the spatial extent of the region (Fig. 5). Application of the criteria to the weather station data produced consistent results. Similarly, the annual rainfall cycle described by the weather station data for Regions 1-3 is qualitatively captured by the FEWS rainfall estimates (Fig. 6) and CRU data (not shown). That is, despite the monthly rainfall totals being underestimated by FEWS, the annual rainfall cycle with respect to the peaks and September hiatus is captured. All subsequent rainfall analyses presented in this study are based on the weather station data.

\subsection{Synoptic type classification}

Figure 7 shows the synoptic type classification produced by the SOM algorithm. Each node in the SOM represents a single SLP anomaly pattern representative of a portion of the 12,053 daily patterns used to train the SOM. The frequency of occurrence for each of the nodes is indicated at the top right of the relevant node, with the node number shown at the top left (Fig. 7).

On a SOM, similar synoptic patterns are grouped together with nodes characterized by very different patterns being further apart. From the Sammon map shown in Fig. 8 it can be seen that the nodes in the top half of the SOM, in particular the top-middle region, are more similar to adjacent nodes compared to the nodes found in the lower half of the SOM. Generally, the lower part of the SOM is occupied by circulation patterns typical of winter, the upper part by circulation patterns typical of summer and the central part by circulation patterns occurring throughout the year. The spatial rainfall distribution associated with the SOM nodes, represented by composites derived from FEWS data and expressed as mm/day, is shown in Fig. 9. The synoptic patterns differentiate between distinct rainfall patterns, including rainfall maxima over the Southwestern Cape (e.g. nodes 1-5) tropical-temperate rainband events (e.g. nodes $22,23,26,33)$, rainfall maxima over the east coast (e.g. nodes $27,28,35$ ) and typical summer convection over central and eastern South Africa (e.g. nodes 17-19). The nodes that occur most frequently during each month of the year may be discerned from analysis presented in Fig. 10. The circulation patterns represented in the lower left corner of the SOM (Fig. 7) are strong frontal troughs that occur most frequently during June to August (Fig. 10g, 
Fig. 7 SOM of SLP anomalies (hPa) based on daily NCEP reanalysis data from 1979 to 2011. Anomaly SLP contour interval is $2 \mathrm{hPa}$. Light and dark shades represent negative and positive SLP anomalies, respectively. The node numbers as well as the node frequency of occurrence are indicated on the figure. Nodes occurring outside the range of $2.56-3.15 \%$, have lower or higher than average occurrences statistical significant at the $95 \%$ confidence level. Clustering of the main synoptic types is indicated and represent ridging high pressure systems southeast of the subcontinent (RE), tropical-temperate troughs (TTT), troughs southwest of the subcontinent (TSW), troughs southeast of the subcontinent (TSE), ridging high pressure systems from the southwest (RSW) and weak synoptic flow (WSF)
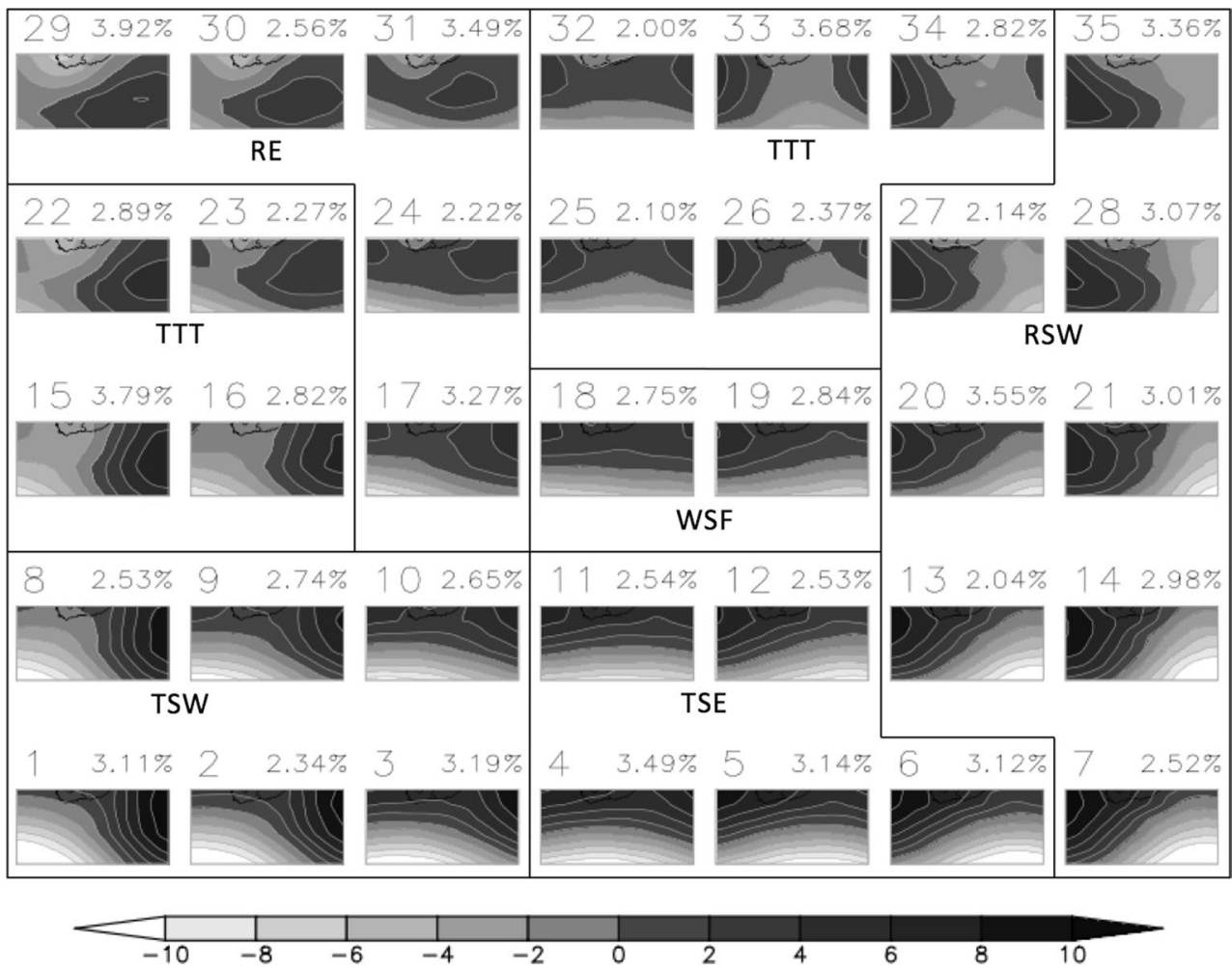

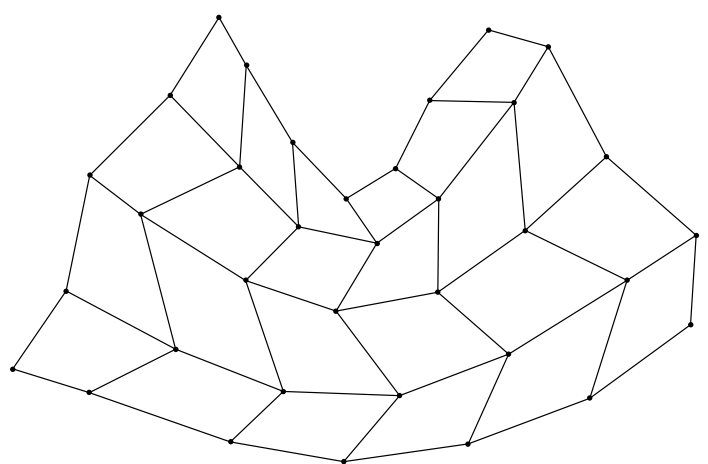

Fig. 8 Sammon map for the SOM shown in Fig. 7

h, i). For September (Fig. 10j), the nodes occurring most frequently are placed in the lower right corner of the SOM. Here, the paths of the frontal troughs are displaced slightly polewards compared to the winter tracks, allowing for the Atlantic Ocean High ( $\mathrm{AOH})$ to extend a ridge along the southern coastal belt of the subcontinent, mainly overland. At the start of the summer season (Fig. 10k, l) and during December (Fig. 10a), ridging high pressure systems from the southwest ridge from further south (nodes middle and upper right part of the SOM) as the frontal troughs continue to be displaced polewards, with a cell of high pressure moving eastwards to be situated southeast of the subcontinent (upper left corner of the SOM). For January, February and March (Fig. 10b, c, d), the nodes in the upper part of the
SOM represent the dominant synoptic types. These nodes are representative of the various configurations of tropicaltemperate troughs, transforming to tropical-temperature linkages over the western interior during April (Fig. 7 node 15, Fig. 10e). By May (Fig. 10f), the nodes representative of frontal troughs that have migrated equatorward after the summer months, are becoming more frequent again.

\subsection{Relative contribution of synoptic types to rainfall over sub-regions}

The regionally averaged daily rainfall associated with each node as well as the percentage contribution of each node to the annual rainfall over each of the regions are shown in Fig. 11. The COLs identified by the tracking algorithm were mapped to the relevant node of the SOM for inclusion in the analysis with regards to the relative contribution of the synoptic types to the annual rainfall over the sub-regions (Fig. 12). During 1979-2011, 222 COL events (511 COL days) were associated with rainfall over the study region. COL-induced rainfall over the study region is mostly associated with COLs located over the southwestern interior and over the ocean to the west of the country (Fig. 12).

Over all the regions, nodes in the upper right part of the SOM are responsible for a relatively large contribution to the annual rainfall (Fig. 11d, e and f). These nodes are typical of the late summer months, February and March 

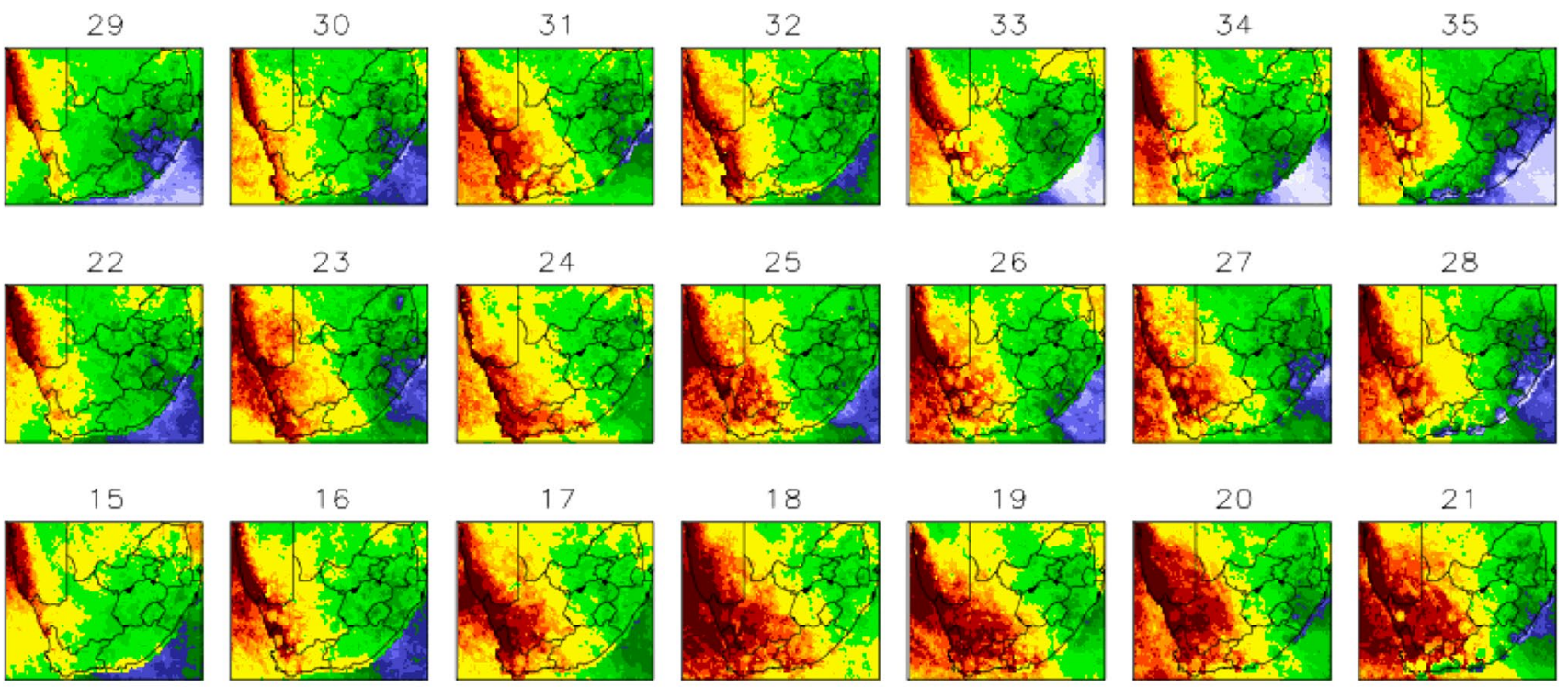

8

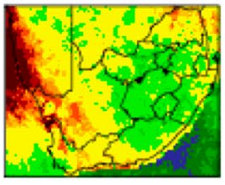

1

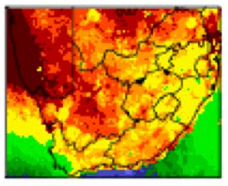

10

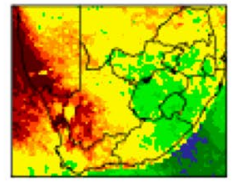

2

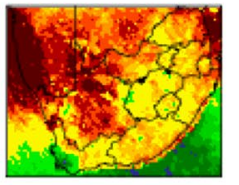

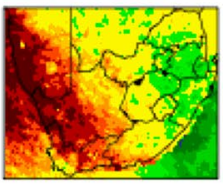

3

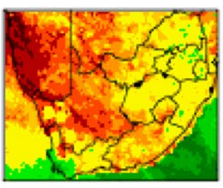

11

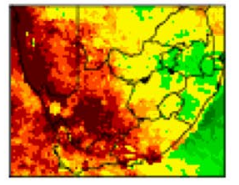

4

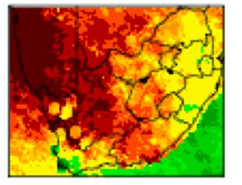

12

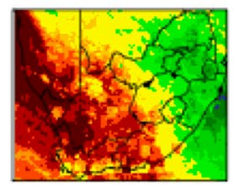

5

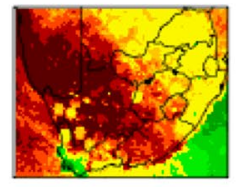

13

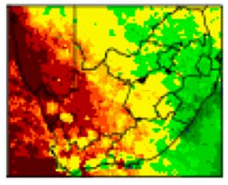

6

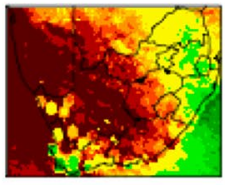

14

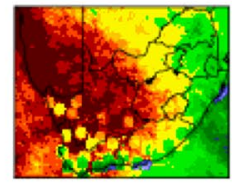

7

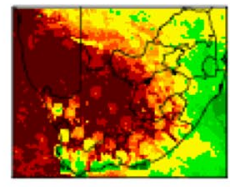

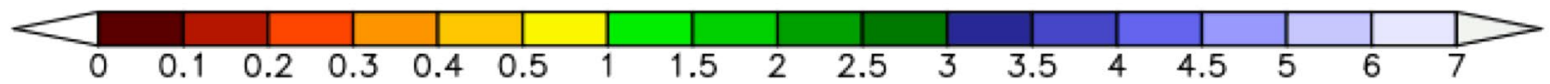

Fig. 9 Rainfall composites expressed as mm/day derived from FEWS data for the period 1983-2011 for each of the SOM nodes as seen in Fig. 7

(Fig. 10). Over the Cape south coast (Region 1), the six nodes in the upper right corner are responsible for $43 \%$ of the annual rainfall (Fig. 11d), while the frequency of occurrence of these nodes is only $17 \%$ (Fig. 7). These nodes represent the $\mathrm{AOH}$ that extends a ridge eastwards at about $40^{\circ} \mathrm{S}$ (nodes 27, 28, 35), as well as tropical-temperate troughs (nodes 26, 33, 34). Node 35 is associated with the largest average daily rainfall over Region 1 (Fig. 11a) and Region 3 (Fig. 11c). It also has a significantly higher than average occurrence, which in combination with the high average daily rainfall totals lead to this node being associated with 13 and $11 \%$ of the annual rainfall over Regions 1 (Fig. 11d) and 3 (Fig. 11f), respectively. It may further be noted that this node is associated with the second highest frequency of COL days associated with rainfall over the region (Fig. 12). Node 14 (Fig. 7) is also associated with high average daily rainfall totals over Region 1 (Fig. 11a).
This node has a maximum frequency of occurrence during winter (Fig. 10), and represents a high pressure system ridging behind a frontal system that is situated southeast of the subcontinent.

Nodes 15, 22 and 29 (Fig. 7) are prominent in contributing to the annual rainfall over Regions 2 (Fig. 11e) and 3 (Fig. 11f). Nodes 15 and 22 represent tropical-temperate linkages. Node 29 is characterized by a high pressure system southeast and south of the subcontinent, and of all the nodes is associated with the highest frequency of COL days (Fig. 12). The association of node 29 with COLs as well as the location of the surface trough in the extreme west are probably the reasons for this node being responsible for the highest average daily rainfall over Region 2 (Fig. 11b). The higher than average occurrence of node 29 is statistically significant at the $95 \%$ confidence level. It contributes $16 \%$ of the annual rainfall occurring over Region 2 (Fig. 11e). 
(a)

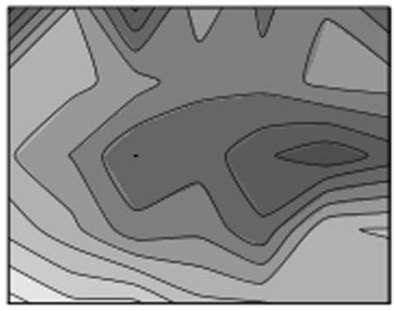

(b) January

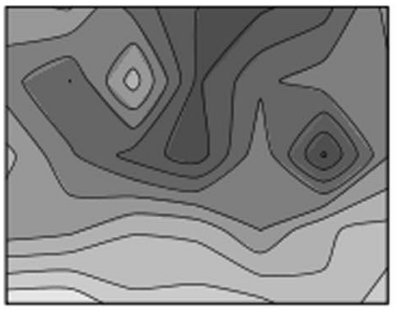

(c) February

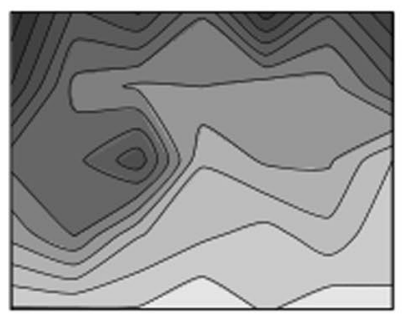

(d)

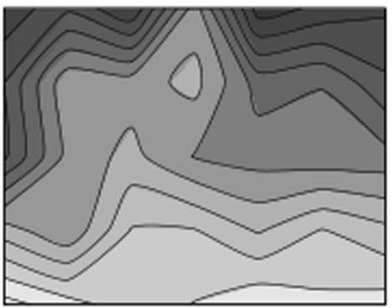

(e)

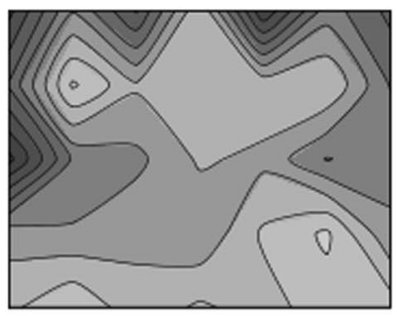

(f)

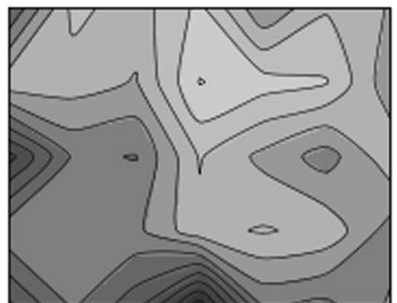

(g)

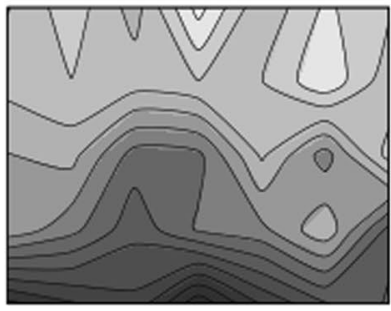

(h)

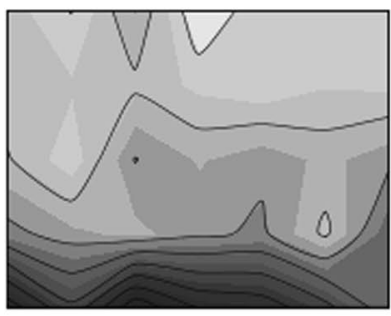

(i)

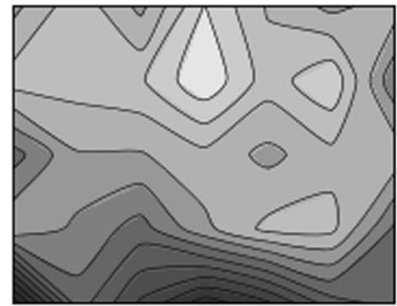

(j) September

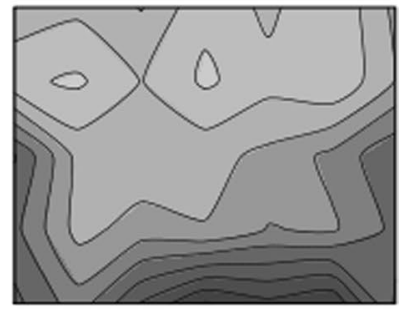

(k) October

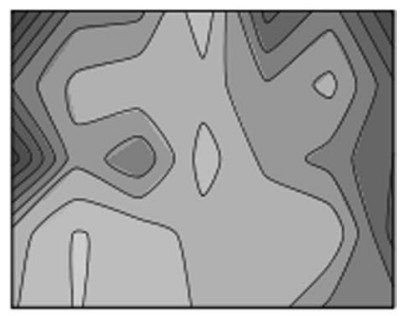

(I) November

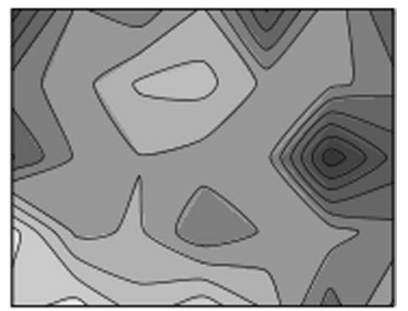

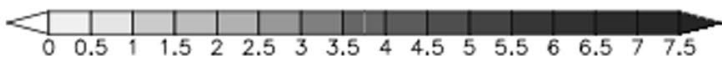

Fig. 10 Node frequencies (\%) for a December (1,023 days), b January (1,023 days), c February (932 days), d March (1,023 days), e April (990 days), f May (1,023 days), g June (990 days), h July
(1,023 days), i August (1,023 days), j September (990 days), k October (1,023 days) and $\mathbf{I}$ November (990 days) that map to each node based on the total days of the particular month from 1979 to 2011
The nodes representative of frontal troughs located in the lower and middle central part of the SOM, are generally associated with small average daily rainfall totals over all the regions, and consequently with the smallest contribution to the annual rainfall.

The 35 synoptic types may be grouped into main synoptic classes that are relevant to the Cape south coast region. These are troughs southwest and southeast of the subcontinent, ridging high pressure systems from the southwest, high pressure systems located east of the subcontinent, tropical-temperate troughs and weak synoptic flow (Fig. 7). The clustering of the 35 nodes into the 6 main synoptic classes is based on additional evaluation of composite maps of the $850,700,500,200 \mathrm{hPa}$ geopotential heights as well as the spatial distribution of rainfall over southern Africa associated with each node. The spatial rainfall distribution over southern Africa is employed to aid in the identification of nodes representative of tropical-temperate troughs - characterized by the presence of a cloud band originating from tropical Africa extending south or southeastwards over South Africa (e.g. Hart et al. 2013). As the station data used is limited to the study region, the FEWS rainfall estimate was employed to represent the spatial rainfall distribution associated with each node over southern Africa (Fig. 9).

Of the six synoptic classes identified, high pressure systems ridging from the southwest contribute most to rainfall over Region 1 (Fig. 13a, bar 3). In fact, the various configurations of these systems are associated with a staggering $46 \%$ of the region's rainfall. The subset of ridging highs from the southwest occurring in conjunction with COLs contributes $7 \%$ to total annual rainfall. It is likely though, that the remaining cases are often associated with other forms of upper-air support (e.g. upper air troughs). Still, this result is indicative that the low-level flow around favorably positioned near-surface highs, and possible interactions with the mountainous topography adjacent to the coastal area, are factors of 
Fig. 11 The regionally averaged daily precipitation $(\mathrm{mm} /$ day) for each SOM node for a Region 1, b Region 2 and c Region 3, and the average annual contribution (\%) by node to rainfall over $\mathbf{d}$ Region 1, $\mathbf{e}$ Region 2 and $\mathbf{f}$ Region 3 (a)

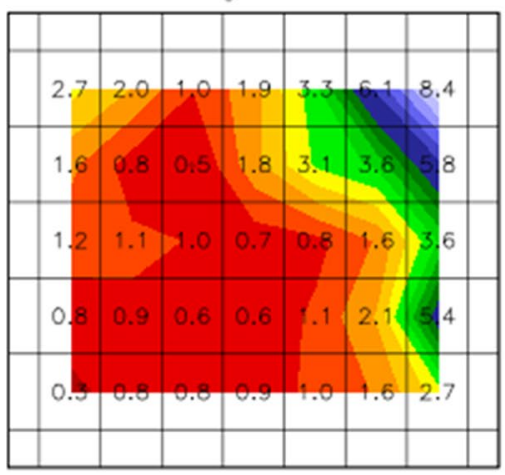

(b)

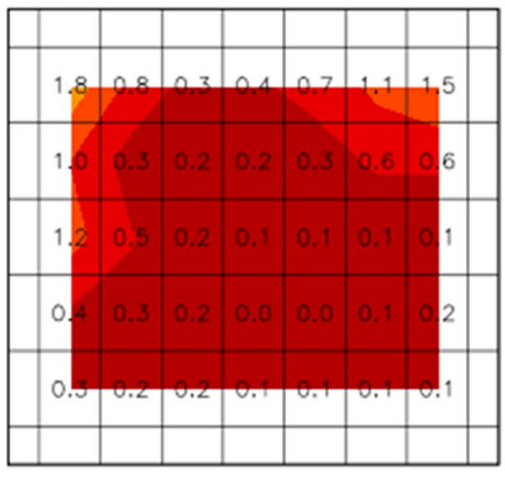

(c) Region 3

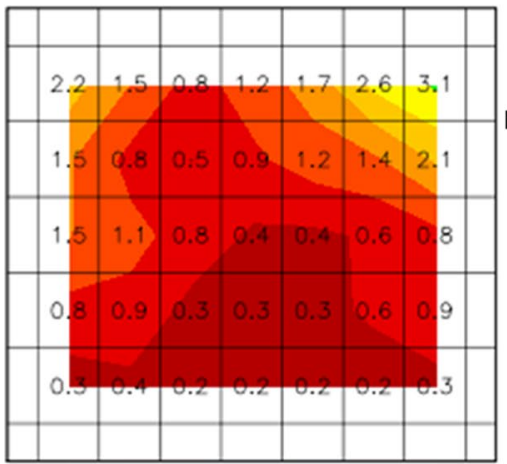

(d)
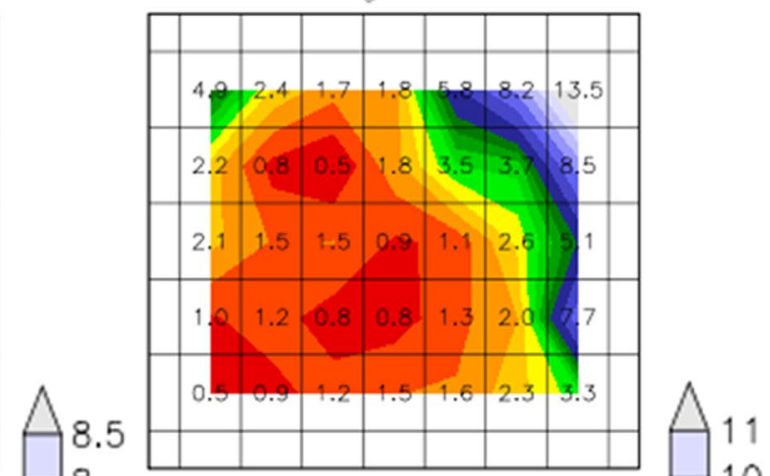

(e)

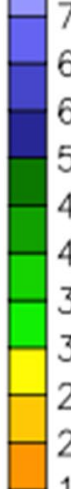

7
6.5
6
5
4.5
4
3.5
3
2.5
2
1.5

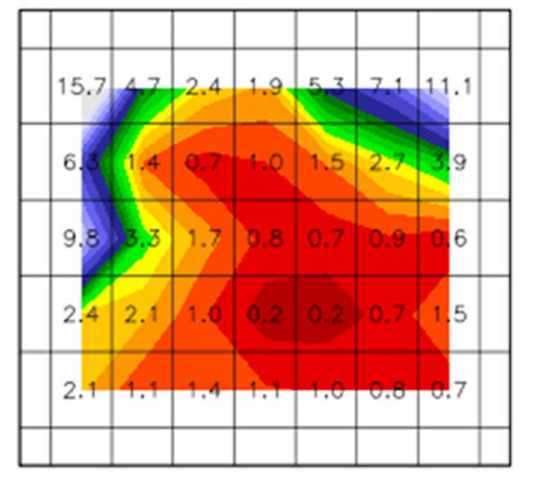

(f)
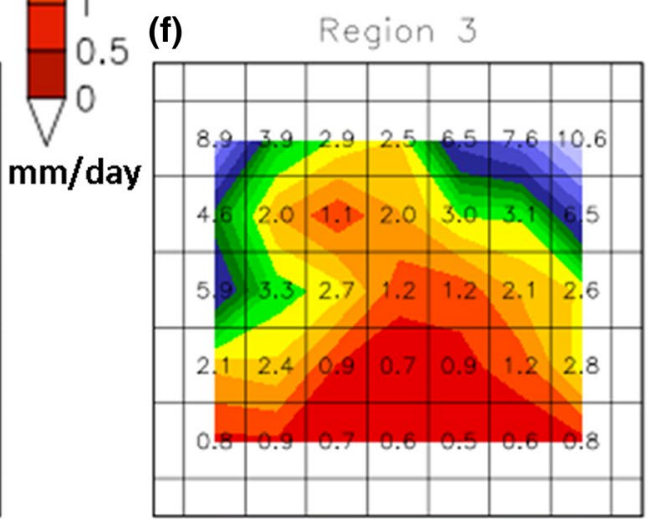

key importance in causing rainfall over the Cape south coast region. Over Regions 2 and 3 (Fig. 13b, c, bar 3), the contribution of ridging high pressure systems from the southwest to the annual rainfall is much less-22 and $30 \%$ respectively (6 and $5 \%$ in conjunction with COLs respectively). This result confirms that it is the low-level flow and interaction with topography that causes this synoptic class to be of key importance to the Cape south coast region itself. Tropical-temperate troughs contribute to 28,38 and $37 \%$ of the annual rainfall over Regions 1,2 and 3 respectively (Fig. 13a, b, c, bar 5). The overall contribution of COLs to annual rainfall over the Cape south coast is $16 \%$, much less than the contribution of
$39 \%$ of ridging highs that occur in the absence of COLs. Regional variation occurs in the contribution of COLs to annual rainfall, as shown in Fig. 14. At the stations in Region 1, the contribution of COLs to annual rainfall ranges between $13 \%$ and $22 \%$. Favre et al. (2013) have found the contribution of COLs to annual rainfall over the Cape south coast to be somewhat higher-in the order of 20-30\%. COLs are estimated to contribute about 24 and $17 \%$ of the annual rainfall over Region 2 and 3 respectively, with the percentage contribution ranging between 13 and $25 \%$ at the various weather stations. Taking into account that only a small number ( 7 on the average) of COLs contribute to rainfall over the Cape 

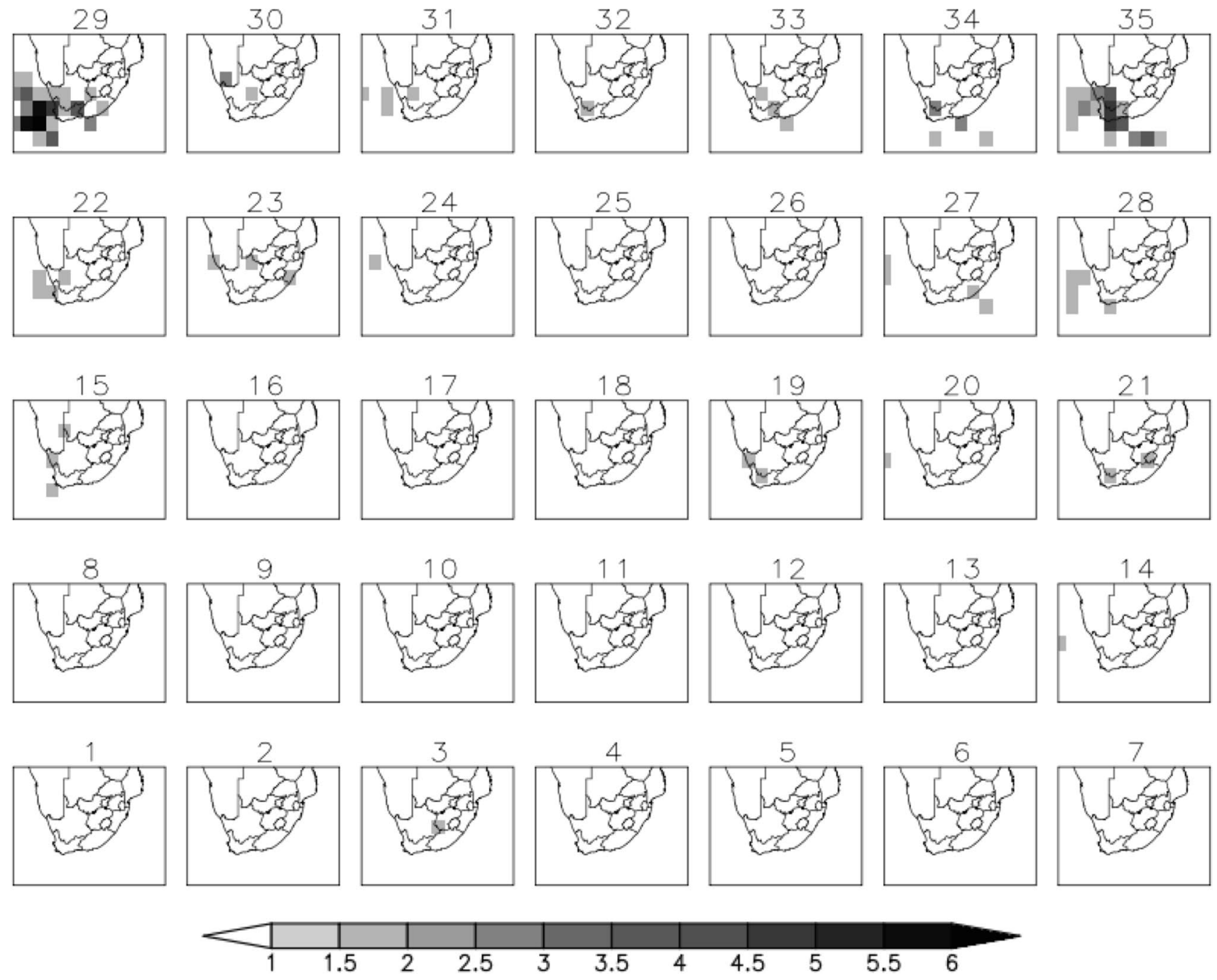

Fig. 12 Accumulated frequency of rainfall-producing COLs (units: COL days/grid point) for each SOM node for the period 1979-2011. Only grid points with a frequency of at least 1 day are indicated

south coast per year, the relatively large portion of rain these systems contribute to the annual rainfall is quite noteworthy. Not surprisingly, when extreme daily rainfall for each station are considered, defined here as the $95^{\text {th }}$ percentile of all recorded rain days, the contribution of COLs to extreme rainfall exceeds that of the contribution of COLs to annual rainfall at all the weather stations (Fig. 14). The largest differrence in the contribution of COLs to annual and extreme rainfall occurs along the coast and adjacent interior, with the COL contribution to extreme rainfall reaching double that of it's annual rainfall contribution at some stations.

The statistics for the nodes associated with the highest average daily rainfall, the highest average contribution to annual rainfall as well as the nodes contributing $>5 \%$ each to average annual rainfall are summarized in Table 1.
3.4 Synoptic types driving the annual rainfall cycle over the Cape south coast

The decomposition of the synoptic types responsible for rainfall over the Cape south coast performed in the previous section shows the relative importance of ridging high pressure systems, tropical-temperate troughs and COLs over this region. The role that each of these systems play in the annual rainfall cycle over the region will subsequently be discussed. Of particular interest is the role of COLs and their association with the observed rainfall peaks (Fig. 6), since COL occurrences over South Africa reach maximum numbers during March-May and October (Singleton and Reason 2007b; Favre et al. 2013), corresponding with two of the three rainfall peaks observed over the Cape south coast region. Moreover, COLs are associated with significant rainfall events along the Cape south coast region (e.g. 
(a) Region 1

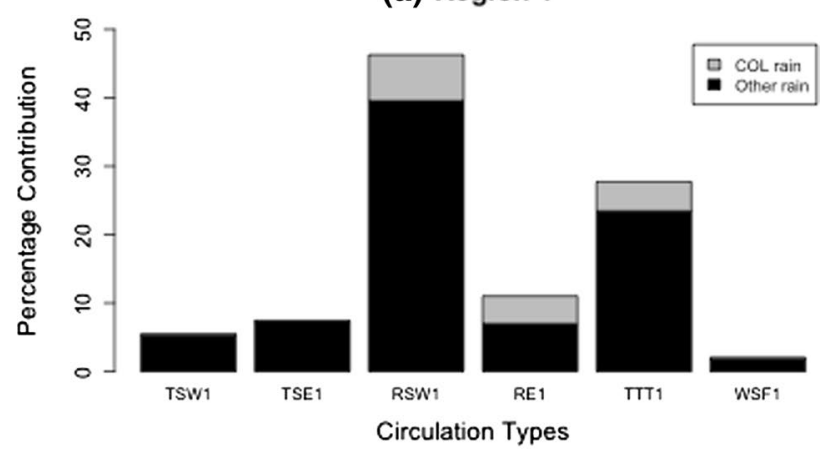

(b) Region 2
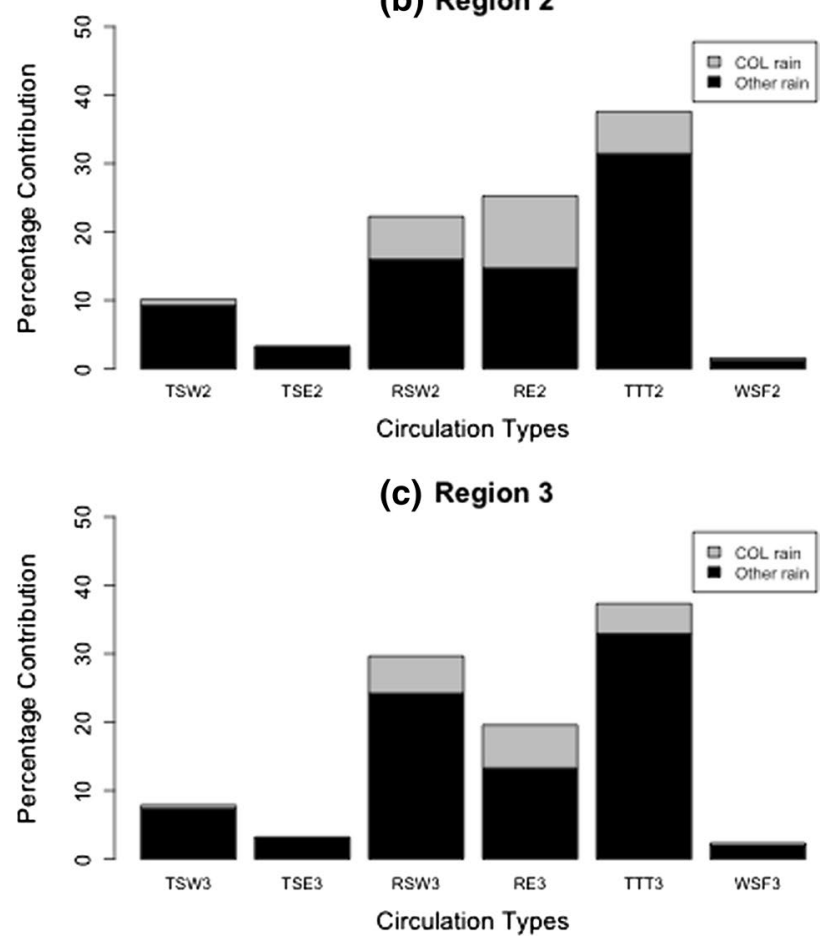

Fig. 13 The percentage contribution to the average annual rainfall of the six main synoptic classes identified in this study for a Region 1, b Region 2 and $\mathbf{c}$ Region 3. The percentage of rainfall contributed by COLs to the average rainfall, in association with the six main synoptic classes, is shown in grey

Taljaard 1985; Singleton and Reason 2006, 2007a, also see Sect. 3.3). In order to investigate the relative contribution of COLs to the rainfall cycle over the Cape south coast, the percentage contribution of COLs to monthly rainfall totals was calculated.

Over the 33-year period analysed, 222 rain-producing COLs occurred that were associated with rainfall over the study region. The preferred geographical location of these COLs is the southwestern interior of South Africa and adjacent oceanic area off the west coast (Fig. 12). This region has been identified by Favre et al. (2013) as being one of the areas of southern Africa with the highest frequency of
COLs. Autumn (March-May) and winter (June-August) have the highest frequency of occurrence of COLs over the study region, with the highest frequencies in April, May and June (Fig. 15).

Synoptic types associated with the March-April rainfall peak over Region 1 (Fig. 16a) include troughs, ridging high pressure systems and tropical-temperate troughs, with nodes $21,28,33,34,35$ being the most prominent in contributing rainfall during March, and nodes 7, 14, 21, 26, 28, 33, 34, 35 the most prominent during April (Fig. 17a). Ridging high pressure systems and tropical-temperate troughs accompanied by COLs contribute to the March rainfall peak while the April rainfall peak is dependent on the contribution by COLs (Fig. 16a). During March, COLs occur in combination with ridging high pressure systems from the southwest and tropical temperate troughs (represented by nodes 26, 27, 34 and 35) (Fig. 17a). The COLinduced rainfall peak during April is characterized by lowlevel circulation representative of ridging high pressure systems from the southwest and- southeast as well as tropical temperate troughs-nodes 21, 22, 29, 34 and 35 are representative of the aforementioned synoptic types (Fig. 17d). Over Region 2, the March-April peak (Fig. 16b) in rainfall is associated with troughs from the southwest, ridging high pressure systems and tropical-temperate troughs. Nodes $9,15,22,29,34$ and 35 are representative of the synoptic types contributing the most to the rainfall peak during March while nodes 15, 16, 17, 28, 29, 33, 34 and 35 are prominent during April (Fig. 17b). The synoptic types associated with COL-induced rainfall that contribute most prominently to the rainfall peak during March are representative of nodes 22, 29, 31 and 35 (Fig. 17e). During April, the rainfall peak receives the largest contribution by COL-induced rain. Nodes 22, 29 and 35 are representative of the synoptic types that accompany COLs during April, with node 29 in particular prominent to contribute to the rainfall peak (Fig. 17e). Over Region 3, January to March experience the same rainfall-producing synoptic types (node 8, 9, 15, 16, 22, 29, 33 and 34), with the rainfall peak occurring in February, driven by tropical-temperate troughs as represented by nodes 15, 22 and 33 (Fig. 17c).

During August, COLs associated with nodes 29 and 35 (Fig. 17d) as well as ridging high pressure systems (nodes $7,14,21,28$ ) and tropical-temperate troughs (nodes 26, 34) contribute to the rainfall peak over Region 1 (Fig. 16a and 17a). Over Regions 2 and 3, the August rainfall peak is significantly less prominent than the autumn and spring peaks. For Region 2, nodes 29 and 35 (Fig. 17e) in combination with COLs as well as nodes 17, 22 and 34 (Fig. 17b) contributes to the small-amplitude August peak in the annual rainfall cycle (Fig. 16b). A small amplitude August rainfall peak is also present over Region 3 (Fig. 16c) and seems to occur in association with synoptic types 13,14 , 
Fig. 14 Percentage contribution of COLs to annual rainfall (grey) and extreme rainfall (black) at the weather stations

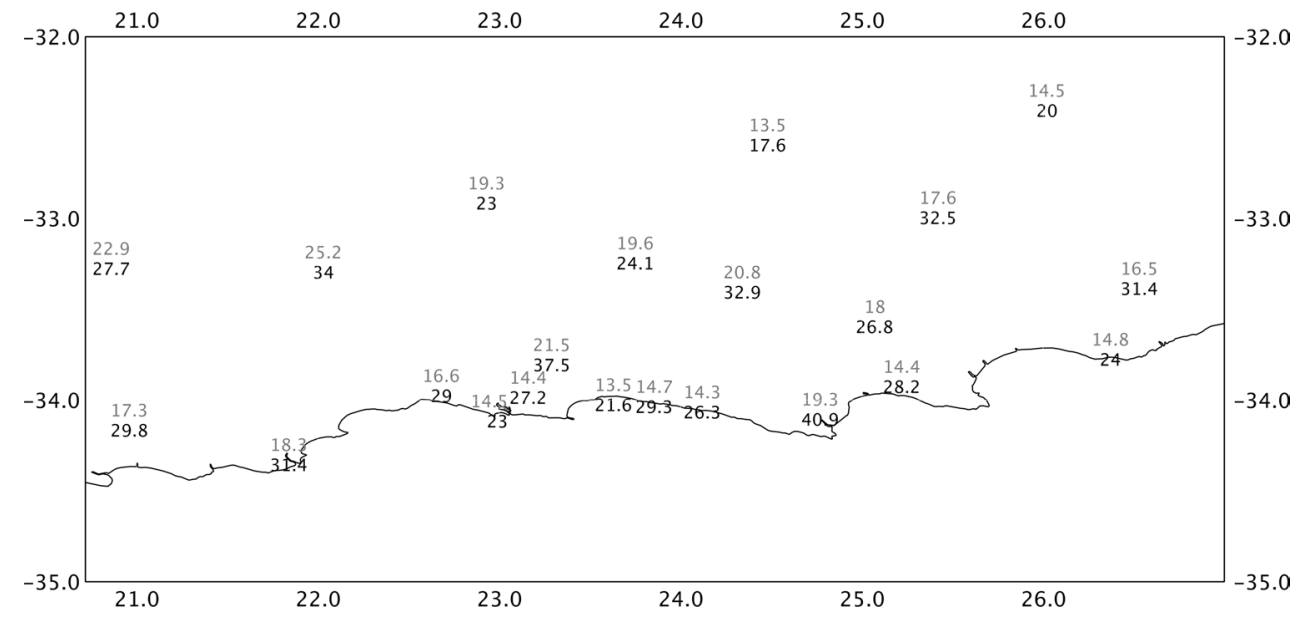

Table 1 Synoptic types most important to rainfall over the Cape south coast and adjacent interior

\begin{tabular}{llll}
\hline Synoptic type rainfall attributes & Region 1 & Region 2 & Region 3 \\
\hline Highest average daily rainfall & $35(8.4 \mathrm{~mm} / \mathrm{day})$ & $29(1.8 \mathrm{~mm} /$ day $)$ & $35(3.1 \mathrm{~mm} / \mathrm{day})$ \\
Highest average contribution to annual rainfall & $35(13 \%)$ & $29(16 \%)$ & $35(11 \%)$ \\
$\begin{array}{l}\text { Nodes contributing }>5 \% \text { each to average annual rainfall } \\
\text { (ranked according to contribution) }\end{array}$ & $35,28,34,1433,21$ & $29,35,15,34,22,33$ & $35,29,34,33,28,15$ \\
\hline
\end{tabular}

Fig. 15 Accumulated monthly number of COLs associated with rainfall at 1 station or more, over the period 1979 2011

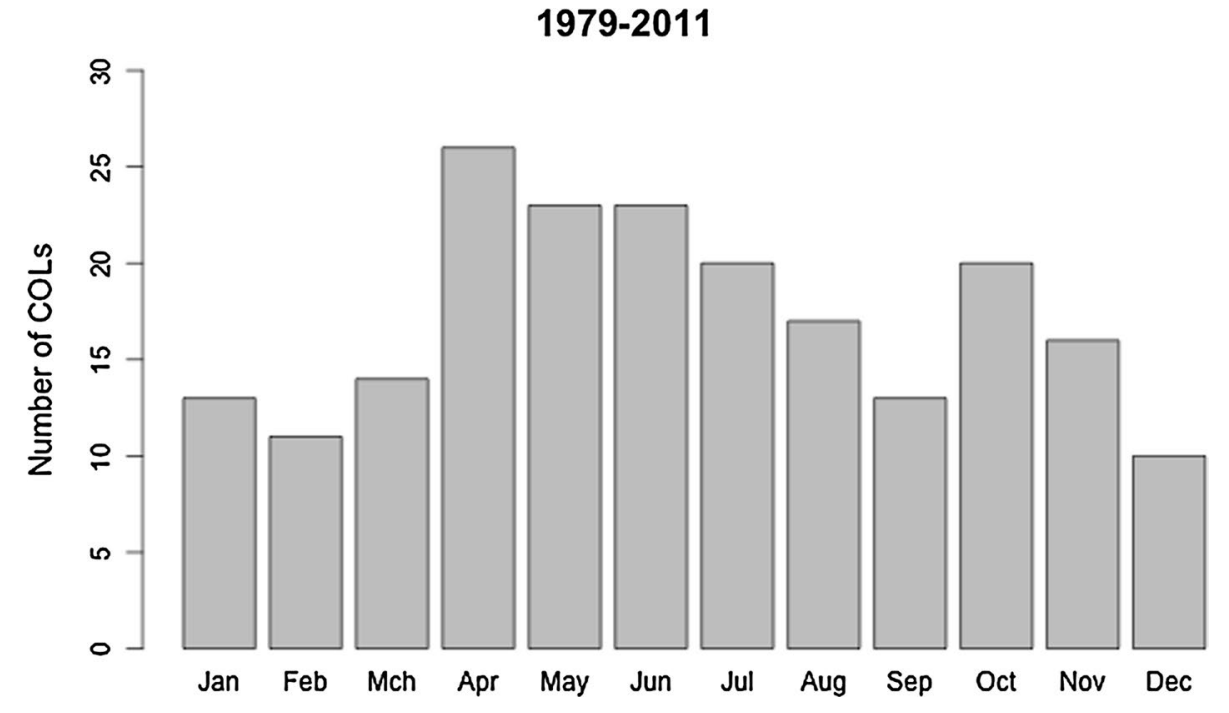

28, 34 and 35 (Fig. 17c) as well as with COLs in combination with nodes 29, 30, 31 and 35 (Fig. 17f).

The month of October is characterized by a prominent rainfall peak over the Cape south coast, and strong rises in the monthly rainfall totals compared to the September totals over all three regions (Fig. 16). However, Fig. 16 also reveals that COL-induced rainfall doesn't peak or rise significantly relative to September totals during October. Ridging high pressure systems from the southwest (nodes 14, 20, 28, 35), tropical-temperate troughs (nodes 33, 34) and high pressure systems southeast of the subcontinent (node 29) are associated with the October rainfall peak over Region 1 (Fig. 17a). Of these weather systems, ridging high pressure systems from the southwest are responsible for the largest contribution to the rainfall peak. Over Regions 2 and 3 ridging high pressure systems from the southwest, a ridge southeast of the subcontinent and tropical-temperate troughs (nodes 15, 28, 29, 34, 35 and nodes $15,28,29,33,34,35$ respectively) are the main synoptic types contributing to the October rainfall (Fig. 17b, c). The 
(a) Area-averaged rainfall: Region 1

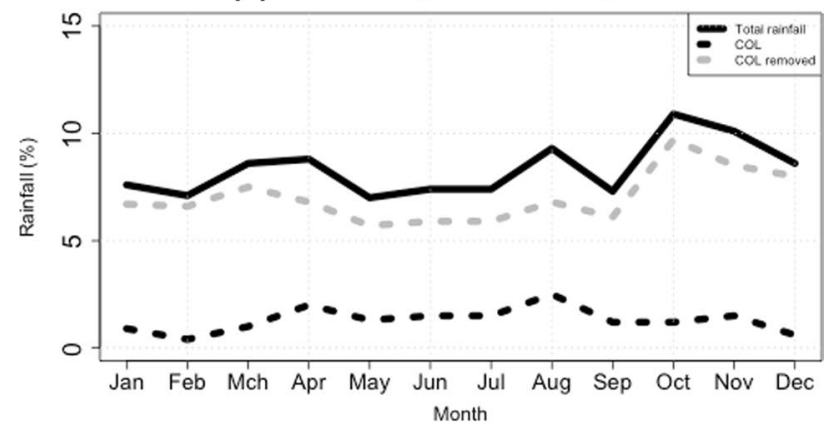

(b) Area-averaged rainfall: Region 2

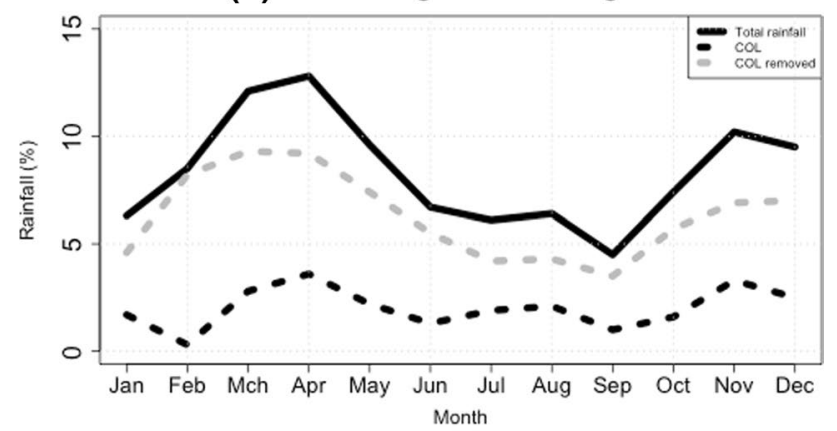

(c) Area-averaged rainfall: Region 3

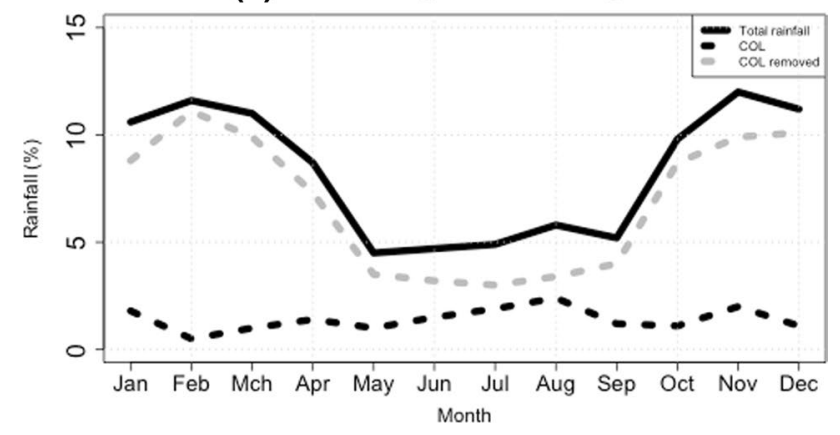

Fig. 16 Area-averaged annual rainfall distribution for the period 1979-2011 over a Region 1, b Region 2 and c Region 3. The black solid line represents the monthly rainfall (\%), the black dotted line the monthly rainfall associated with COLs (\%) and the grey dotted line the monthly rainfall without the COL-induced rainfall (\%)

largest contribution to the October rainfall over Region 2 is from a ridge southeast of the subcontinent, represented by node 29 (Fig. 17b) while node 35 (ridge from the southwest) is associated with the largest contribution to October rainfall over Region 3 (Fig. 17c). The November rainfall peaks over Region 2 (Fig. 16b) and Region 3 (Fig. 16c) can be ascribed to COLs and their interaction with ridging high pressure systems southeast of the subcontinent, tropicaltemperate troughs as well as high pressure systems ridging from the southwest. The nodes representative of these circulation patterns are nodes 19, 22, 29, 33, 35 (Fig. 17e) and nodes 22, 29, 34, 35 (Fig. 17f) for Region 2 and 3 respectively. COLs also contribute to the relatively high rainfall totals over Region 1 in November (Fig. 16a). November is the month with the highest frequency of tropical-temperate troughs (Hart et al. 2013), consistent with the accumulated contribution of nodes 22 and 29 (representative of tropicaltemperate troughs) that occur in combination with COLs, to outscore the contribution of high pressure systems southeast and southwest of the subcontinent that are associated with COL-induced rain.

\section{Conclusions}

The Cape south coast of South Africa, here defined as the region between 21 and $27^{\circ} \mathrm{E}$ and south of the Cape Folded mountains (that is, south of about $33.7^{\circ} \mathrm{S}$ ), is an all-year rainfall region. Over this region, at least 11 but mostly all 12 months of the year contribute $5 \%$ or more to the longterm average annual rainfall total, in both gridded (CRU TS3.1 and FEWS) and weather station data analysed over the region. Other features that distinguish the region from the winter and summer rainfall regions of South Africa is the relatively high ratio of the rainfall total for the month of minimum rainfall to the total for the month of maximum rainfall, and the relatively small average fluctuation of monthly rainfall totals around the monthly mean rainfall total.

The SOM technique was used to develop a synoptic climatology for the Cape south coast of South Africa, and the synoptic forcing of rainfall over the region was subsequently analysed. The synoptic types identified depend to some extent on the specific reanalysis data set used. Here NCEP reanalysis daily SLP anomaly data were used to train a $7 \times 5$ SOM. SLP was selected as the metric for synoptic typing due to the Cape south coast region being close to sea-level (different metrics such as $850 \mathrm{hPa}$ heights would lead to the identification of somewhat different types). A number of well-known synoptic classes, such as ridging highs, tropical-temperate troughs and weak synoptic flow have been identified by the SOM, as well as subtle but systematic differences within different synoptic types that make up the main classes. The importance of the SOM to capture these subtle differences is illustrated by the nodes' very different contributions to annual rainfall over the region. This is applicable in particular to the rain-producing synoptic types, such as ridging high pressure systems from the southwest and tropical-temperate troughs. For example, the results presented in this paper indicate that ridging high pressure systems where the ridge is located further southwards are more conducive to rainfall along the Cape south coast region than ridges located more equatorwards, even if the pressure distribution is otherwise similar. A similar observation was made regarding the intensity of the ridging high pressure systems. It has long been known that 
(a)

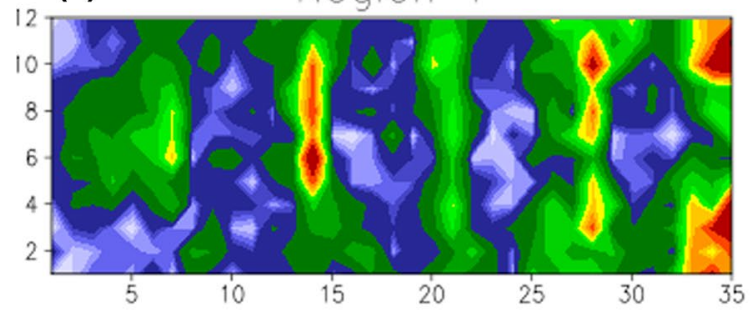

(b)

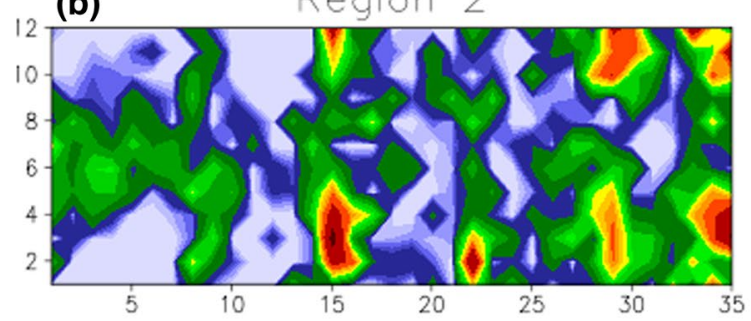

(d)

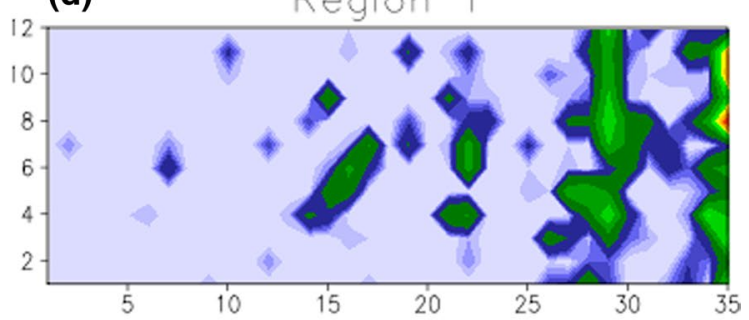

(e)

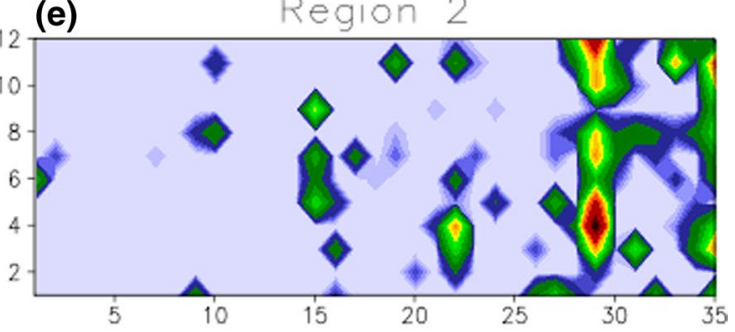

(c) Region 3

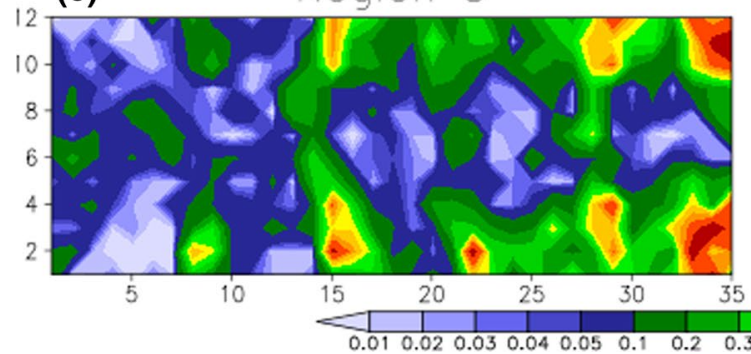

(f) Region 3

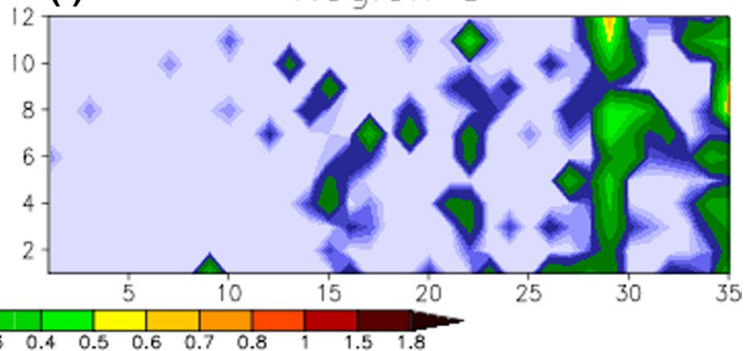

Fig. 17 Percentage contributions of monthly rainfall totals to the average annual rainfall (y-axis) not associated with COLs for a Region 1, b Region 2, $\mathbf{c}$ Region 3 and associated with COLs for $\mathbf{d}$ Region 1, e Region 2 and $\mathbf{f}$ Region 3. The 35 SOM nodes are indicated on the $\mathrm{x}$-axis

the geographical location and the intensity of ridging high pressure systems is a determining factor for the occurrence of rainfall and the nature of the rainfall over the Cape south coast region (e.g. Taljaard 1996). However, by application of a SOM, it is possible to quantify the rainfall associated with the different types within a main synoptic class. For example, over the 33-year period node 27 (ridging high pressure system from the southwest) yielded $3.6 \mathrm{~mm} /$ day, whereas node 28 (also a ridging high- pressure system from the southwest) yielded $5.8 \mathrm{~mm} /$ day. Similarly, ridging high pressure systems from the southwest represented by nodes 20 and 21 yielded approximately 1.6 and $3.6 \mathrm{~mm} /$ day. Taking the frequency of occurrence of the synoptic types into account, the contribution by a single type within a main synoptic class (e.g. ridging highs) becomes important with regard to seasonal or annual rainfall totals.

Ridging high pressure systems are the synoptic types that contribute most to rainfall totals over the Cape south coast region. These systems have a frequency of occurrence of $23 \%$ (of the total number of daily occurrences of synoptic types) but contribute $46 \%$ of the total rainfall over the Cape south coast. Over Regions 2 and 3, the contribution of ridging high pressure systems to rainfall totals is notably less, which suggests that topography plays some part in enhancing the rainfall along the coast (Region 1). Tropicaltemperate troughs are responsible for $28 \%$ of the rainfall over Region 1, increasing northwards to contribute $38 \%$ and $37 \%$ to annual rainfall over Regions 2 and 3. The frequency of occurrence of the various configurations of tropical-temperate troughs accumulates to $25 \%$. COLs occur in combination with ridging high pressure systems (ridging from the southwest and southeast) and tropical-temperate troughs. However, the contribution to rainfall by COLs has been isolated from these systems for comparison purposes using an objective tracking algorithm. COLs contribute $16 \%$ (7\% in co-occurrence with ridging highs), 24 and $17 \%$ to the annual rainfall over Regions 1, 2 and 3 respectively. The contribution to rainfall by COLs is remarkable, considering that the COL-induced rainfall days over the Cape south coast region amount only to $4.2 \%$. Transient frontal troughs were found to bring the least rain to Region 1 of the rain-bearing systems, consistent with the observations of the winter months being associated with a season characterized by lower rainfall totals compared to 
transitional seasons. The estimated relative contribution of synoptic types to annual rainfall depends to some extent on the spatial coverage and distribution of the weather stations recording rainfall.

The autumn and August rainfall peaks observed in the annual rainfall cycle over the Cape south coast (Region 1) cannot be attributed to a single rain-producing synoptic type. Both ridging highs, tropical-temperate troughs and COLs have been shown to contribute to these rainfall peaks, but with COLs driving the rainfall peak during April. COLs are the single synoptic type driving the subtle August rainfall peak over Region 3. The September hiatus in rainfall that occurs across the three regions, after the August peak, seems to be related to a poleward displacement of frontal systems and positioning of high pressure systems (ridging mainly over land) that are both unfavorable for rainfall. Along the Cape south coast, the October rainfall peak is the highest rainfall peak observed during the year. This rainfall peak is the result of ridging high pressure systems and to a lesser extent tropical-temperate troughs, with an insignificant contribution by COLs. The increase in rainfall during October is also observed over the interior regions. However, the rainfall peak over Regions 2 and 3 occurs in November when an increase in COL-induced rainfall is observed over all the regions, although very slight over Region 1 . This November peak over Region 2 and 3 can largely be attributed to COLs. Noteworthy is the importance of ridging high pressure systems relative to COLs for the existence of the October rainfall peak along the coast (Region 1).

Acknowledgments This research was funded by the Water Research Commission (Project K5/2257/1) and the Applied Centre for Climate and Earth System Studies (ACCESS) in South Africa. Rainfall data were supplied by the South African Weather Servicethe assistance of Elsa de Jager is greatly acknowledged. The editing contributions of Dr. Fyfield from the Agricultural Research Council are highly valued and acknowledged. Two anonymous reviewers are thanked for their constructive comments.

\section{References}

Crimp SJ, van den Heever SC, D'Abreton PC, Tyson PD, Mason SJ (1997) Mesoscale modelling of tropical-temperature troughs and associated systems over southern Africa. WRC Report 595/1/97

Engelbrecht CJ, Engelbrecht FA, Dyson LL (2013) High-resolution model-projected changes in mid-tropospheric closed-lows and extreme rainfall events over southern Africa. Int J Climatol 33:173-187. doi:10.1002/joc. 3420

Fauchereau N, Pohl B, Reason CJC, Rouault M, Richard Y (2009) Recurrent daily OLR patterns in the Southern Africa/Southwest Indian Ocean region, implications for South African rainfall and teleconnections. Clim Dyn 32:575-591. doi:10.1007/ s00382-008-0426-2

Favre A, Hewitson B, Tadross M, Lennard C, Cerezo-Mota R (2012) Relationships between cut-off lows and the semiannual and southern oscillations. Clim Dyn 38:1473-1487. doi:10.1007/ s00382-011-1030-4
Favre A, Hewitson B, Lennard C, Cerezo-Mota R, Tadross M (2013) Cut-off lows in the South Africa region and their contribution to precipitation. Clim Dyn 41:2331-2351. doi:10.1007/ s00382-012-1579-6

Harris I, Jones PD, Osborn TJ, Lister DH (2014) Updated high-resolution grids of monthly climatic observations: the CRU TS3.10 dataset. Int J Climatol 34:623-642. doi:10.1002/joc.3711

Hart NCG, Reason CJC, Fauchereau N (2010) Tropical-extratropical interactions over Southern Africa: three cases of heavy summer season rainfall. Mon Weather Rev 138:2608-2623

Hart NCG, Reason CJC, Fauchereau N (2012) Building a tropical-extratropical cloud band metbot. Mon Weather Rev 140:4005-4016

Hart NCG, Reason CJC, Fauchereau N (2013) Cloud bands over southern Africa: seasonality, contribution to rainfall variability and modulation by the MJO. Clim Dyn 42:1199-1212. doi:10.1007/s00382-012-1589-4

Hayward LQ, van den Berg H (1968) Die port Elizabeth-stortreens van 1 September 1968. SA Weather Bureau News Letter No. 234, 157-169

Hayward LQ, van den Berg H (1970) The Eastern Cape Floods of 24 to 28 August, 1970. SA Weather Bureau News Letter No. 257, 129-141

Hewitson BC, Crane RG (2002) Self-organizing maps: applications to synoptic climatology. Clim Res 22:13-26

Jury MR, Levey K (1993) The climatology and characteristics of drought in the eastern Cape of South Africa. Int J Climatol 13:629-641. doi:10.1002/joc.3370130604

Kalnay E, Kanamitsu M, Kistler R, Collins W, Deaven D, Gandin L, Iredell M, Saha S, White G, Woollen J, Zhu Y, Leetmaa A, Reynolds B, Chelliah M, Ebisuzaki W, Higgins W, Janowiak J, Mo KC, Ropelewski C, Wang J, Jenne R, Joseph D (1996) The NCEP/NCAR 40-year reanalysis project. Bull Am Meteorol Soc 77:437-471

Katzfey JJ, McInnes KL (1996) GCM simulations of Eastern Australia cutoff lows. J Clim 9:2337-2355

Kohonen T (2001) Self-organizing maps. 3rd ed. Springer

Landman WA, Mason SJ, Tyson PD, Tennant WJ (2001) Retro-active skill of multi-tiered forecasts of summer rainfall over southern Africa. Int J Climatol 21:1-19

Malherbe J, Engelbrecht FA, Landman WA, Engelbrecht CJ (2012) Tropical systems from the southwest Indian Ocean making landfall over the Limpopo River Basin, southern Africa: a historical perspective. Int J Climatol 32:1018-1032. doi:10.1002/joc.2320

Muller A, Reason CJC, Fauchereau N (2008) Extreme rainfall in the Namib Desert during late summer 2006 and influences of regional ocean variability. Int J Climatol 28:1061-1070. doi: $10.1002 /$ joc. 1603

Philippon N, Rouault M, Richard Y, Favre A (2011) The influence of ENSO on winter rainfall in South Africa. Int J Climatol 32:23332347. doi: $10.1002 /$ joc. 3403

Roberts CPR, Alexander WJR (1982) Lessons learnt from the 1981 Laingsburg flood. Civ Eng S Afr 24:17-21, 24-25, 27

Rouault M, Richard Y (2003) Intensity and spatial extension of drought in South Africa at different time scales. Water SA 29:489-500

Rouault M, White SA, Reason CJC, Lutjehams JRE, Jobard I (2002) Ocean-atmosphere interaction in the Agulhas current region and a South African extreme weather event. Weather Forecast 17:655-669

Schuenemann KC, Cassano JJ, Finnis J (2009) Synoptic forcing of precipitation over Greenland: climatoloy for 1961-99. J Hydrometeorol 10:60-78

Singleton AT, Reason CJ (2006) Numerical simulations of a severe rainfall event over the Eastern Cape coast of South Africa: sensitivity to sea surface temperature and topography. Tellus 58:355-367 
Singleton AT, Reason CJ (2007a) A numerical model study of an intense cutoff low pressure system over South Africa. Mon Weather Rev 135:1128-1150

Singleton AT, Reason CJ (2007b) Variability in the characteristics of cut-off low pressure systems over subtropical southern Africa. Int J Climatol 27:295-310

Sylla MB, Giorgi F, Coppola E, Mariotti L (2013) Uncertainties in daily rainfall over Africa: assessment of gridded observation products and evaluation of a regional climate model simulation. Int J Climatol 33:1805-1817. doi:10.1002/joc.3551

Taljaard JJ (1985) Cut-off lows in the South African region. South African Weather Bureau, Technical paper 14

Taljaard JJ (1995) Atmospheric circulation systems, synoptic climatology and weather phenomena of South Africa. Part 2: Atmospheric circulation systems in the South African region. South African Weather Bureau, Technical paper 28

Taljaard JJ (1996) Atmospheric circulation systems, synoptic climatology and weather phenomena of South Africa. Part 6: Rainfall in South Africa. South African Weather Bureau, Technical paper 32

Tennant WJ (2003) An assessment of intraseasonal variability from 13-yr GCM Simulations. Mon Weather Rev 131:1975-1991

Tennant WJ (2004) Considerations when using pre-1979 NCEP/NCAR reanalysis in the southern hemisphere. Geophys Res Lett 31:L11112. doi:10.1029/2004GLO197501

Tennant WJ, Hewitson BC (2002) Intra-seasonal rainfall characteristics and their importance to the seasonal prediction problem. Int $\mathbf{J}$ Climatol 22:1033-1048. doi:10.1002/joc.778
Tennant WJ, van Heerden J (1994) The influence of orography and local sea-surface temperature anomalies on the development of the 1987 Natal floods: a general circulation model study. SuidAfrikaanse Tydskrif vir Wetenskap 90:45-49

Tozuka T, Abiodun BJ, Engelbrecht FA (2014) Impacts of convection schemes on simulating tropical-temperate troughs over southern Africa. Clim Dyn 42:433-451. doi:10.1007/s00382-013-1738-4

Van Rooy MP (1972) Climate of South Africa: district rainfall for South Africa and the annual March of rainfall over southern Africa, part 10. South African Weather Bureau Tech. Note WB 35, Department of Transport, Pretoria, South Africa

Van Schalkwyk L, Dyson LL (2013) Climatological characteristics of fog at Cape Town International airport. Weather Forecast 28:631646. doi:10.1175/WAF-D-12-00028.1

Washington R, Todd M (1999) Tropcial-temperate links in the Southern African and southwest Indian Ocean satellite-derived daily rainfall. Int J Climatol 19:1601-1616

Weepener HL, van den Berg HM, Metz M, Hamandawana H (2012) The development of a hydrologically improved Digital Elevation Model and derived products for South Africa based on the SRTM DEM. Water Research Commission, Pretoria. Report No. 1908/1/11. Press ISBN 978-1-4312-0217-1

Weldon D, Reason CJC (2014) Variability of rainfall characteristics over the South Coast region of South Africa. Theor Appl Climatol 115:177-185. doi:10.1007/s00704-013-0882-4 